\title{
Characterisation of the circulating acellular proteome of healthy sheep using LC-MS/ MS-based proteomics analysis of serum
}

\author{
Saul Chemonges ${ }^{1 *} \mathbb{D}$, Rajesh Gupta ${ }^{2}$, Paul C. Mills ${ }^{1}$, Steven R. Kopp ${ }^{1}$ and Pawel Sadowski ${ }^{2}$
}

\begin{abstract}
Background: Unlike humans, there is currently no publicly available reference mass spectrometry-based circulating acellular proteome data for sheep, limiting the analysis and interpretation of a range of physiological changes and disease states. The objective of this study was to develop a robust and comprehensive method to characterise the circulating acellular proteome in ovine serum.

Methods: Serum samples from healthy sheep were subjected to shotgun proteomic analysis using nano liquid chromatography nano electrospray ionisation tandem mass spectrometry (nanoLC-nanoESI-MS/MS) on a quadrupole time-of-flight instrument (TripleTOF ${ }^{\circledR}$ 5600+, SCIEX). Proteins were identified using ProteinPilot ${ }^{\text {TM }}$ (SCIEX) and Mascot (Matrix Science) software based on a minimum of two unmodified highly scoring unique peptides per protein at a false discovery rate (FDR) of $1 \%$ software by searching a subset of the Universal Protein Resource Knowledgebase (UniProtKB) database (http://www.uniprot.org). PeptideShaker (CompOmics, VIB-UGent) searches were used to validate protein identifications from ProteinPilot ${ }^{\mathrm{TM}}$ and Mascot.
\end{abstract}

Results: ProteinPilot ${ }^{\mathrm{TM}}$ and Mascot identified 245 and 379 protein groups (IDs), respectively, and PeptideShaker validated 133 protein IDs from the entire dataset. Since Mascot software is considered the industry standard and identified the most proteins, these were analysed using the Protein ANalysis THrough Evolutionary Relationships (PANTHER) classification tool revealing the association of 349 genes with 127 protein pathway hits. These data are available via ProteomeXchange with identifier PXD004989.

Conclusions: These results demonstrated for the first time the feasibility of characterising the ovine circulating acellular proteome using nanoLC-nanoESI-MS/MS. This peptide spectral data contributes to a protein library that can be used to identify a wide range of proteins in ovine serum.

Keywords: Sheep serum, Ovine circulating acellular proteome, nanoLC-nanoESI-MS/MS, Gene ontology, Protein pathway analysis, Sheep serum proteomics, Proteogenomics data

\section{Background}

There is currently no publicly available reference mass spectrometry-based circulating acellular proteome data for sheep. However, the well-defined serum proteome of humans permits analysis and interpretation of a range of physiological changes and disease states $[1,2]$. To date, the serum proteome of sheep is largely extrapolated from cattle, which can be inaccurate despite a $97 \%$

\footnotetext{
*Correspondence: s.chemonges@uq.edu.au

'School of Veterinary Science, The University of Queensland, Gatton, Australia
} Full list of author information is available at the end of the article similarity in protein coding sequences [3] and different promoters driving the expression of specific proteins [4]. Characterisation of the serum proteome of sheep would therefore be useful to quantify disease in this species.

Sheep are a major production species, providing meat and wool, plus are used in a range of biotechnological and translational studies [5-9]. Despite this, relatively little is known about the responses of sheep to a range of physiological and pathological events, including the effects of breed differences in these responses. There is therefore a need to comprehensively characterise the proteins in ovine serum for better quantitative assessment of disease 
and any alternations in physiology and pathology. Blood is relatively easily collected from sheep [10-14], but comparatively only a small number of proteins have been identified, limiting the capacity to assess disease $[10,15]$. One problem to date is that protein sample preparation in published studies on sheep have been inadequate and have generally ignored the full conventions for reporting identified proteins from samples $[16,17]$. Consequently, data are lacking on optimised sample preparation approaches for shotgun proteomics workflows using more than one protein sequence search engine to explore the circulating acellular proteome of sheep. For example, the number of proteins identified by single laboratories using gel fractionation followed by MS from human plasma has been in the region of nearly 300 protein identifications (IDs) [18]. In 2005, liquid chromatography tandem mass chromatography (LC-MS/MS) data from multiple sample preparation techniques and protein sequence search engines for the Human Plasma Proteome Project (HPPP) from 18 laboratories worldwide collectively identified 3,020 plasma proteins based on a minimum of 2-high-scoring peptides $[19,20]$. This number of protein IDs from HPPP studies was subsequently revised to 889 [19, 21]. A study that used high performance liquid chromatography (RPHPLC) and LC-ESI-MS/MS to analyse and define the human baseline plasma proteome identified 200 proteins [22]. More recently, protein expression profiles of human plasma proteins using one-dimensional sodium dodecyl sulfate polyacrylamide gel electrophoresis (1D SDSPAGE) coupled with nanoLC-ESI-MS/MS in a single laboratory identified 253 proteins after desalting of the peptides [23]. A similar approach to that used in the preceding study was considered attractive to be used in exploring the circulating acellular proteome of sheep.

The present study used nano liquid chromatography nano electrospray ionisation tandem mass spectrometry (nanoLC-nanoESI-MS/MS) to analyse peptides derived from healthy sheep serum samples following 1D SDSPAGE and in-solution digestion.

\section{Methods}

\section{Overview of methods}

This study used universal protein extraction techniques detailed hereinafter to comprehensively define the serum proteome of healthy sheep. Because of the genome of sheep being incompletely sequenced or annotated, proteins were identified by matching tryptic peptides against a composite protein sequence database of sheep, goat and ox using ProteinPilot ${ }^{\mathrm{Tm}}$ Software (SCIEX) in the first instance in order to capture homologous sequences. The inclusion of protein sequences from related species is a helpful strategy when exploring and establishing foundation proteogenomics data to identify known or novel genes of the non-model study subject - in this case sheep [24-30]. Mascot [31] (Matrix Science) search was subsequently conducted using a sheep-only protein sequence database to identify high-scoring proteins and PeptideShaker [32] (CompOmics, VIB-UGent) to verify protein identifications from the primary search data.

\section{Animal care, sample collection, storage and preparation} Serum samples of healthy adult female Merino sheep $(n=$ 6) with ear tag identification numbers $473,413,463,471$, 476 and 478 belonging to an experimental colony at Queensland University of Technology (QUT) and the Australian Red Cross Blood Service (ARCBS) were obtained for the development and optimisation of a comprehensive proteomic approach for interrogating the circulating acellular proteome. The sheep were reared according to established standard operating procedures, described elsewhere [33]. Sample aliquots of $500 \mu \mathrm{L}$ were stored in $1.5 \mathrm{~mL}$ Eppendorf tubes at $-80{ }^{\circ} \mathrm{C}$ at the ARCBS, Brisbane. The samples were transferred to the wet laboratory at the Molecular Genetics Research Facility (MGRF) within Central Analytical Research Facility (CARF), QUT for processing. The processed samples were analysed by nanoLC-nanoESI-MS/MS at the Proteomics and Small Molecule Mass Spectrometry laboratory at CARF, QUT.

\section{Sample preparation for protein analysis}

Frozen sheep serum samples were thawed on ice and then centrifuged at $13,000 \mathrm{~g}$ at $4{ }^{\circ} \mathrm{C}$ for $20 \mathrm{~min}$. The sediment and top layer comprising mainly of lipids and suds were discarded, retaining the supernatant. The protein concentration in the supernatant was determined with bicinchoninic acid (BCA) protein assay kit (BCA Protein Assay Kit, Pierce ${ }^{\mathrm{Tm}}$ ) according to the manufacturer's instructions using a spectrophotometer (NanoDrop 2000, Thermo Scientific). The supernatant was then either directly analysed or concentrated by acetone precipitation of proteins. In some experiments, a protease inhibitor cocktail tablet (Roche) was added into the sample after thawing, according to the manufacturer's instructions.

\section{Acetone precipitation of proteins}

Proteins in serum were precipitated by adding $4 \times(\mathrm{v}: \mathrm{v} \%)$ of cold $\left(-20^{\circ} \mathrm{C}\right)$ acetone and then incubated at $-20{ }^{\circ} \mathrm{C}$ for $16 \mathrm{~h}$, prior to centrifugation at $4,000 \mathrm{~g}$ for $2 \mathrm{~min}$. The supernatant was discarded. The pellet was washed with cold acetone and the suspension was centrifuged at 4,000 $g$ for $5 \mathrm{~min}$ at $4{ }^{\circ} \mathrm{C}$. The supernatant was discarded and this procedure was repeated one more time. The pellet was then dissolved in freshly prepared $8 \mathrm{M}$ urea in $25 \mathrm{mM}$ ammonium bicarbonate $\left(\mathrm{NH}_{4} \mathrm{HCO}_{3}\right)$ (Sigma-Aldrich) buffer. The mixture was centrifuged at $4,000 \mathrm{~g}$ for $5 \mathrm{~min}$ at $4{ }^{\circ} \mathrm{C}$, the supernatant was kept and the insoluble sediment was discarded. The protein concentration of the supernatant was determined using the BCA method [34]. 


\section{D SDS-PAGE}

The universal 1D SDS-PAGE procedure used to fractionate proteins was based on its established description [35] and subsequent refinements [36-39]. The detailed description is provided in Additional file 1.

The gels were stained with Coomassie brilliant blue (EZ-Run $^{\mathrm{Ts}}$, Protein Gel Staining Solution, Fisher Scientific) according to the manufacturer's instructions and then photographed using a handheld camera (5.7-inch Quad HD Super AMOLED ${ }^{\circ}$, Samsung; or New 8megapixel iSight camera with $1.5 \mu$ pixels with Optical image stabilisation, iPhone 6, Apple Inc.).

Gel bands from entire single lanes were excised into 12 approximately equal portions into a clean $1.5 \mathrm{~mL}$ Eppendorf tube and de-stained using 50\% acetonitrile (ACN) (Optima ${ }^{\oplus}$, Fisher Scientific) in $25 \mathrm{mM} \mathrm{NH}_{4} \mathrm{HCO}_{3}$ accompanied by agitation at $750 \mathrm{rpm}$ for $20 \mathrm{~min}$ at RT. This procedure was repeated and alternated with washing the gel bands with $25 \mathrm{mM} \mathrm{NH}_{4} \mathrm{HCO}_{3}$ buffer. Once de-stained, final washing of the gel bands was performed using LC-MS grade water followed by incubation for $20 \mathrm{~min}$ at RT. The water was discarded and the gel bands were cut into approximately $1 \mathrm{~mm}^{3}$ pieces using a $10 \mathrm{uL}$ pipette tip. Gel bands were dehydrated by adding $100 \% \mathrm{ACN}$ and agitating at $750 \mathrm{rpm}$ for $10 \mathrm{~min}$ at RT prior to drying in a vacuum centrifuge (SpeedVac Concentrator $\mathrm{Christ}^{\oplus}$ cat. No. RVC 2-33 IR), for $10 \mathrm{~min}$.

In-gel proteins were reduced in order to break disulphide bonds and alkylated to prevent the bonds reforming as originally described elsewhere [40]. Briefly, freshly prepared $10 \mathrm{mM}$ DTT (Sigma-Aldrich) in $25 \mathrm{mM} \mathrm{NH}_{4} \mathrm{HCO}_{3}$ buffer was added sufficiently to cover the vacuum dried gel pieces and agitated at $750 \mathrm{rpm}$ for $45 \mathrm{~min}$ at $56{ }^{\circ} \mathrm{C}$. Twice the amount of DTT as of freshly prepared $55 \mathrm{mM}$ iodoacetamide (IAM) (Sigma-Aldrich) in $25 \mathrm{mM} \mathrm{NH} \mathrm{NHCO}_{3}$ buffer was added to the sample and agitated for $30 \mathrm{~min}$ at RT in the dark. The reagents were washed off with $25 \mathrm{mM} \mathrm{NH}_{4} \mathrm{HCO}_{3}$ buffer with agitation for $5 \mathrm{~min}$ at RT, before centrifuging briefly and discarding the supernatant. Gel bands were then dehydrated using 100\% ACN and agitated at $1400 \mathrm{rpm}$ for $10 \mathrm{~min}$ at RT. The entire supernatant was discarded prior to drying the gel pieces in a vacuum centrifuge as above for $20 \mathrm{~min}$.

Vacuum-dried gel pieces were incubated on ice for $5 \mathrm{~min}$ before adding $0.005 \mu \mathrm{g} / \mu \mathrm{L}$ solution of freshly prepared ice-cold working solution of trypsin (Trypsin Gold, Mass Spectrometry Grade, Promega) in $50 \mathrm{mM}$ $\mathrm{NH}_{4} \mathrm{HCO}_{3}$ buffer enough to cover the dry gel pieces [41] and left incubating for a further $30 \mathrm{~min}$ until the entire enzyme solution had entered the gel pieces. Gel pieces were then covered in $50 \mathrm{mM} \mathrm{NH} \mathrm{mHCO}_{3}$ buffer and left to incubate for $16 \mathrm{~h}$ at $37{ }^{\circ} \mathrm{C}$ on an agitator at $300 \mathrm{rpm}$. Digestion was stopped by adding $100 \mu \mathrm{L}$ of $5 \%$ formic acid (FA) (Sigma-Aldrich). Peptide extraction was performed by agitating the gel pieces at 1,000 rpm for $15 \mathrm{~min}$ at RT. The peptide-containing supernatant was collected into a clean $0.5 \mathrm{ml}$ low binding Eppendorf tube. Gel pieces were further washed by adding 5\% FA in $50 \% \mathrm{ACN}$ and agitating at 1,000 rpm for $15 \mathrm{~min}$, before collecting the supernatant. Gel bands were further extracted by adding $100 \% \mathrm{ACN}$ and agitation at 1,000 rpm for $15 \mathrm{~min}$ at RT. The entire supernatant was collected and then completely vacuum-dried prior to reconstitution in $10 \mu \mathrm{L}$ of $0.1 \%$ trifluoroacetic acid (TFA) (Sigma-Aldrich) in $2 \% \mathrm{ACN}$ followed by desalting of peptides.

\section{In-solution digestion of proteins}

The method adapted here was based on the one established by Villén and Gygi [42]. Briefly, a known quantity of serum or plasma protein sample was thawed on ice at $4{ }^{\circ} \mathrm{C}$ after which freshly prepared $20 \mathrm{mM}$ DTT (equal $\mathrm{v}: \mathrm{v} \%$ of sample) was added, vortexed and briefly centrifuged. The mixture was diluted fivefold with $25 \mathrm{mM}$ $\mathrm{NH}_{4} \mathrm{HCO}_{3}$ buffer (v:v\% of sample) to dilute down urea concentration below $1 \mathrm{M}$, followed by adding an equivalent (v:v\% of sample) of aqueous $70 \mathrm{mM} \mathrm{CaCl} \mathrm{Cl}_{2}$. Trypsin was then added at enzyme to substrate (protein concentration of sample) ratio of 1:50. The contents were incubated for $16 \mathrm{~h}$ at $37{ }^{\circ} \mathrm{C}$ and then cooled to RT. Digestion was stopped by adding $50 \mu \mathrm{L}$ of $10 \%$ TFA before vacuum concentrating the contents to dryness. The dried peptides were reconstituted in aqueous $0.1 \%$ TFA in $2 \% \mathrm{ACN}$, and followed by desalting of peptides.

\section{Desalting of tryptic peptide digests}

It is often necessary to remove salts and particulate matter including excess trypsin from peptide digests prior to analysis to prevent blockage of nanoLC columns and also to reduce noise artefacts of MS spectra [43-45]. Desalting of tryptic peptide digests was optimised and performed using either octadecyl carbon chain $\left(\mathrm{C}_{18}\right)$ pipette tips (ZipTip Pipette Tips, Millipore, or Pierce $\mathrm{C}_{18}$ Tips, Thermo Fisher Scientific) depending on the filter capacity according to manufacturer's instructions. Briefly for the $\mathrm{C}_{18}$ tips, the desalting pipette tip was conditioned using a solution of $50 \%$ ACN/0.05\% trifluoroacetic acid (TFA) in LC-MS grade water (Optima ${ }^{\circledR}$, Fisher Scientific) and then equilibrated with $2 \% \mathrm{ACN} / 0.1 \%$ TFA in LCMS water. After carefully and gently pipetting the entire sample up and down for at least 10 times, the membrane was washed with $2 \% \mathrm{ACN} / 0.1 \%$ TFA in LC-MS water. The peptides were eluted using 70\% ACN/0.1\% TFA in LC-MS water, vacuum dried and reconstituted in $10 \mathrm{uL}$ of $2 \% \mathrm{ACN} / 0.1 \% \mathrm{FA}$ in LC-MS water and transferred into a polypropylene autosampler vial for nanoLCnanoESI-MS/MS analysis. 


\section{nanoLC-nanoESI-MS/MS}

\section{Chromatography}

Peptide spectral data from approximately $400 \mathrm{ng}-1 \mu \mathrm{g}$ of injected tryptic peptides per sample were generated using nanoLC-nanoESI-MS/MS on a TripleTOF ${ }^{\circledR} 5600+$ System (SCIEX) instrument. Peptides were separated by performing reversed-phase chromatography using an Eksigent ekspert ${ }^{\text {tam }}$ nanoLC 400 System directly coupled to the MS/MS instrument. The LC platform was setup in a trap and elute configuration with a $10 \mathrm{~mm} \times$ $0.3 \mathrm{~mm}$ trap cartridge packed with ChromXP C18CL $5 \mu \mathrm{m} 120 \AA$ material and a $150 \mathrm{~mm} \times 75 \mu \mathrm{m}$ analytical column packed with ChromXP C18 $3 \mu \mathrm{m} 120 \AA$ (Eksigent Technologies, Dublin, CA). The mobile phase solvents were composed of mobile phase $\mathrm{A}$ : water/0.1\% FA; mobile phase B: ACN/0.1\% FA; and mobile phase C: water $/ 2 \%$ ACN $/ 0.1 \%$ FA. Trapping was performed in mobile phase $\mathrm{C}$ for $5 \mathrm{~min}$ at $5 \mathrm{uL} / \mathrm{min}$ followed by an elute configuration across a $90 \mathrm{~min}$ gradient using two mobile phases $\mathrm{A}$ and $\mathrm{B}$. To minimise retention time drift, the analytical column was maintained at $40{ }^{\circ} \mathrm{C}$.

\section{Data dependent acquisition (DDA)}

The DDA mode of the instrument was set to obtain high resolution $(30,000)$ TOF-MS scans over a mass range of $350-1350 \mathrm{~m} / z$, followed by up to 40 (top 40) high sensitivity MS/MS scans of the most abundant peptide ions per cycle. The selection criteria for the peptide ions included intensity greater than $150 \mathrm{cps}$ and charge state of $2-5$. The dynamic exclusion duration was set at $12 \mathrm{~s}$ to account for the difference in chromatographic peak width matching to the peaks in the chromatogram. Each survey (TOF-MS) scan lasted $0.25 \mathrm{~s}$ and the product ion (MS/MS) scan lasted $0.05 \mathrm{~s}$ resulting in a total cycle time of $2.3 \mathrm{~s}$. The ions were fragmented in the collision cell using rolling collision energy, and CES was set to 5 . The collected peptide ion fragmentation spectra were stored in .wiff format (SCIEX).

\section{Data processing \\ Primary protein sequence database search for protein identification}

The acquired MS/MS data from the instrument were extracted and annotated with amino acid sequences from a custom built database using the Paragon ${ }^{\mathrm{Tm}}$ Algorithm: 5.0.0.0, 4767 [46] (ProteinPilot ${ }^{\text {Tm }}$ Software 5.0, Revision Number: 4769, SCIEX, USA.). The custom composite database (62,025 sequences; 29,099,284 residues) used in Paragon $^{\mathrm{Tw}}$, with added common contaminants was assembled in FASTA format downloaded on $29^{\text {th }}$ July, 2015 from a repository of non-redundant and predicted protein sequences of Ovis aries, Bos taurus and Capra hircus sourced from UniProtKB (Universal Protein Resource Knowledgebase - http://www.uniprot.org/). Another sheep
(Ovis aries) only custom database (27,393 sequences, 13,114,569 residues) with added contaminants from The common Repository of Adventitious Proteins, cRAP (http://www.thegpm.org/crap/) was assembled in FASTA format (26 Jul, 2016) from UniProtKB was used for sheep protein validation. For ProteinPilot ${ }^{\text {tw }}$ searches, the following settings were selected: Sample type: Identification; Cys Alkylation: Iodoacetamide; Digestion: Trypsin; Instrument: TripleTOF 5600+; Special Factors: Urea denaturation; Species: None; Search effort: Thorough ID; ID Focus: Amino acid substitution; Results Quality: Detected protein threshold [Unused ProtScore (Conf)] $\geq 0.05$ with false discovery rate (FDR) selected. Annotations were only retrieved from UniProt during composite searches. The automatically generated Excel spreadsheet (Microsoft ${ }^{\circ}$ Excel 2010, Microsoft Corporation) report in ProteinPilot ${ }^{\mathrm{mex}}$ output was manually inspected for FDR cut-off protein yields and then meticulously curated to filter out contaminants, protein identifications with 0 (zero) unused confidence scores, proteins with reversed (nonsense) sequences and redundant protein IDs. Only proteins identified at FDR $\leq 1 \%$ with $\geq 2$ peptides were considered for protein lists and for visual comparative analysis in the first instance and further downstream analysis.

The group file data in ProteinPilot ${ }^{\mathrm{Tw}}$ were exported as calibrated Mascot generic format (.mgf) and mzIdentML (.mzid) format files. The .mgfs were further reformatted by an mgf repair tool (SCIEX) to recalibrate .mgf files so that they can be parsed to recognise the boundaries between original files and avoid collisions in spectrum identifiers, prior to loading via a Daemon application to Mascot search engine (Matrix Science, London, UK; version 2.5.1) [31]. Mascot was set up to search the same custom database that was used in ProteinPilot ${ }^{\mathrm{Tm}}$ with the following search parameters: type of search: MS/MS ion search; enzyme: trypsin; fixed modifications: Carbamidomethyl (C); variable modifications: deamidated (NQ), oxidation (M); mass values: monoisotopic; protein mass: unrestricted; peptide mass tolerance: $\pm 10 \mathrm{ppm}$; fragment mass tolerance: $\pm 0.01 \mathrm{Da}$; max missed cleavages: 1 ; instrument type: ESI-QUAD-TOF, and the auto-decoy search option was selected. Protein identifications were made at a significance threshold of $p<0.05$ or target decoy of $1 \%$ FDR. Peak list and identification data from the search were exported in a .dat format for further processing. Protein lists were exported in csv format for immediate data evaluation and curation to remove contaminants in Excel spreadsheet. Only proteins identified with 2 or more peptides were included for further evaluation.

\section{Secondary protein sequence database search for protein identification and validation}

The .mgf, dat and .mzIdentML (from ProteinPilot ${ }^{\mathrm{m}}$ ) files were also loaded for protein identification and validation 
using PeptideShaker [32]. Peak lists obtained from MS/ MS spectra were identified using Mascot [31]. Protein identification was conducted against a concatenated target/decoy [47] version of the Ovis aries (27,284; 99.5\%) complement of the UniProtKB, 27,411 (target) sequences. The decoy sequences were created by reversing the target sequences in SearchGUI. The identification settings were as follows: Trypsin with a maximum of 1 missed cleavages; $10.0 \mathrm{ppm}$ as MS1 and 0.5 Da as MS2 tolerances; fixed modifications: carbamidomethylation of $\mathrm{C}(+57.021464 \mathrm{Da})$, variable modifications: deamidation of $\mathrm{N}(+0.984016 \mathrm{Da})$, deamidation of Q (+0.984016 Da), oxidation of $\mathrm{M}(+15.994915 \mathrm{Da})$, pyrolidone from $\mathrm{E}$ $(-18.010565 \mathrm{Da})$ and pyrolidone from Q (-17.026549 Da), fixed modifications during refinement procedure: carbamidomethylation of C (+57.021464 Da). All algorithmpecific settings are listed in the Certificate of Analysis available in the data files.

Peptides and proteins were inferred from the spectrum identification results using PeptideShaker version 1.13.0 [32]. Peptide Spectrum Matches (PSMs), peptides and proteins were validated at a $1.0 \%$ False Discovery Rate (FDR) estimated using the decoy hit distribution. All validation thresholds are listed in the Certificate of Analysis available in the data files. Post-translational modification localisations were scored using the D-score [48] and the phosphoRS score [49] with a threshold of 95.0 as implemented in the compomics-utilities package [50]. Protein identification reports were exported in .xlsx format for evaluation and curation in Excel spreadsheet. Only proteins identified with 2 or more validated peptides were included for further evaluation.

Protein lists were presented in spreadsheet and charts were made (Microsoft $^{\oplus}$ Excel $^{\mathrm{TM}}$ 2010, Microsoft Corporation). Data were visualised using BioVenn Software [51], where appropriate.

The mass spectrometry data along with the identification results were deposited to ProteomeXchange Consortium [52] via the proteomics identifications (PRIDE) partner repository [53] with the dataset identifiers PXD004989 and 10.6019/PXD004989 with the following data access details: Reviewer account details: Username: reviewer99399@ebi.ac.uk; Password: QBFFTGzl

\section{Analytical samples, experimental layout and data collection}

In order to characterise the serum proteome of sheep, two universal sample preparation strategies for shotgun proteome analysis [54] were employed in three paired sets of experiments (first, second and third), using in-gel and in-solution protein digestion of serum samples. This was followed by peptide analysis by nanoLC-nanoESIMS/MS using the method described above.

\section{D SDS-PAGE of normal sheep serum workflow}

As a pilot study, an acetone precipitated serum sample obtained from one sheep (Sheep ID 473) was processed and subjected to 1D SDS-PAGE to ascertain the feasibility of obtaining protein identification data as a basis for constructing a peptide spectral library in future (First ingel digestion). In order to determine the optimum amount of serum protein to load, 2, 10 and $22 \mu \mathrm{g}$ of protein were run in separate wells of the same gel. To determine the amount of protein that needed to be loaded on a gel for protein bands to be visualised after using EZRun protein stain, 250, 500 and 2500 fmol of bovine serum albumin (BSA) protein were loaded in separate wells of another gel and run.

In order to increase the protein coverage, a fraction of acetone precipitated serum sample from Sheep ID 473 was subjected to 1D SDS-PAGE in two gels run concurrently (second in-gel digestion). One gel was loaded with $50 \mu \mathrm{g}$ and $100 \mu \mathrm{g}$ of protein in adjacent lanes and the second gel was also loaded with $50 \mu \mathrm{g}, 100 \mu \mathrm{g}$ and $50 \mu \mathrm{g}$ in adjacent lanes.

In order to determine the effect of the quantity of protein loaded, acetone precipitation and a protease inhibitor on protein coverage, pooled serum samples from six healthy sheep (Sheep IDs 413, 463, 471,473, 476 and 478) were processed and subjected to $1 D$ SDS-PAGE in three gels (third in-gel digestion). The samples utilised consisted of crude protein $(200 \mu \mathrm{g}$ and $100 \mu \mathrm{g})$ on one gel and then $100 \mu \mathrm{g}$ of acetone precipitated serum protein with or without a protease inhibitor (Roche) and $100 \mu \mathrm{g}$ of crude serum in a second gel. A third gel was loaded and run identically as the second gel.

\section{In-solution digestion of sheep serum workflow}

As a pilot study, $10 \mu \mathrm{g}$ of acetone precipitated serum sample obtained from one sheep was subjected to insolution digestion to ascertain the feasibility of obtaining protein identification data as a basis for protein quantitation in future (first in-solution digestion). In order to determine the effect of using unfractionated sample on protein coverage, a fraction of $20 \mu \mathrm{g}$ of crude serum sample from the sheep used in the first in-gel digestion was subjected to in-solution digestion and analysed (second in-solution digestion). A third experiment utilised $100 \mu \mathrm{g}$ of pooled crude serum samples from all six sheep (Sheep IDs 473, 413, 463, 471, 476 and 478) for insolution digestion in order to determine the effect of using a higher quantity of protein substrate on protein coverage (third in-solution digestion).

\section{Results}

The results of the first, second and third in-gel digestions are presented in Figs. 1, 2 and 3, respectively. The details of the individual gels are provided in the figure captions. 


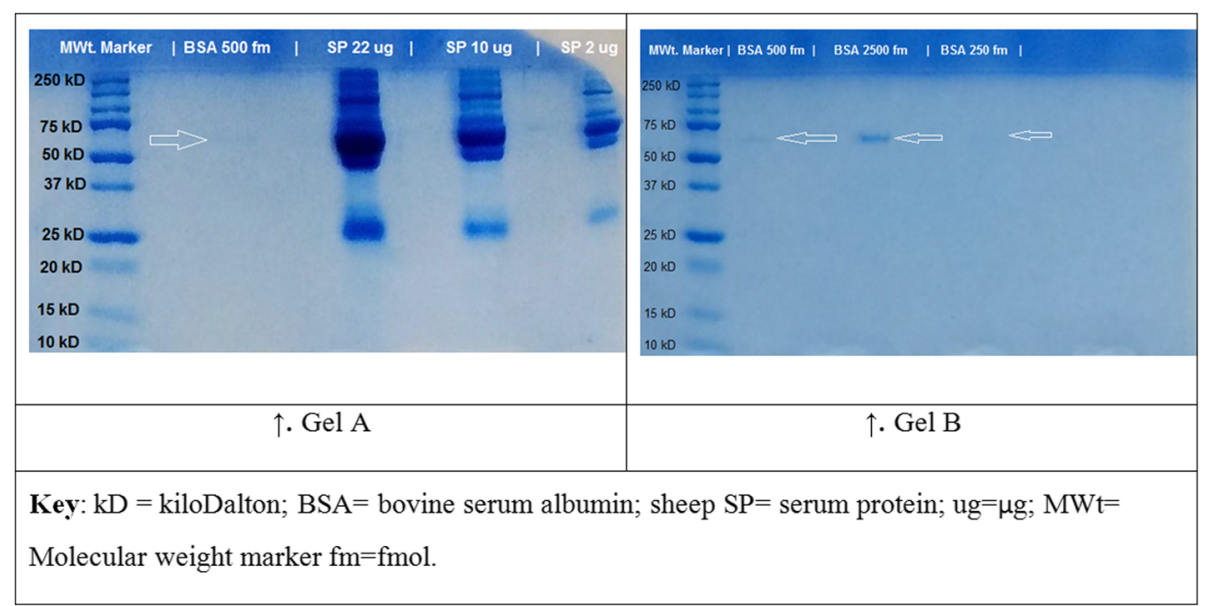

Fig. 1 Coomassie-stained 1D SDS-PAGE gels used in first in-gel digestion. Fractions of acetone precipitated serum protein from a healthy sheep were loaded alongside bovine serum albumin (BSA) in Gel A. Gel A suffered a handling artefact to the top right corner of the gel. The leftmost well of both gels were loaded with $4 \mathrm{\mu L}$ of a protein molecular weight standard (Precision Plus Protein ${ }^{\text {TM }}$ Dual Xtra, Bio-Rad Laboratories). One well in Gel A was loaded with $500 \mathrm{fm}$ of BSA standard; other three wells were loaded with $22 \mu \mathrm{g}, 10 \mu \mathrm{g}$ and $2 \mu \mathrm{g}$ each of sheep serum protein sample. After the molecular weight standard, the other three wells in Gel B were loaded with $500 \mathrm{fm}, 2500 \mathrm{fm}$ and $250 \mathrm{fm}$ each of BSA standard. Arrows show BSA standard

Except for Gel B of in Fig. 1, the protein sample lanes of all the other gels were subjected to in-gel digestion followed by nanoLC-nanoESI-MS/MS to identify proteins. The protein ID results of the first, second and third in-gel and insolution digestions are summarised in Table 1. The detailed results are presented in the accompanying spreadsheet Microsoft $^{\circ}$ Excel $^{\text {Tm }}$ file [see Additional file 2]. Protein IDs were obtained using ProteinPilot ${ }^{\mathrm{tm}}$ [55] to search a UniProtKB composite database of Ovis aries, Bos taurus and Capra hircus with a results quality of FDR $\leq 1 \%$; $\geq 2$ peptides for a protein to be considered confidently identified as the highest scoring member of the protein group. The Pro Group $^{\text {tw }}$ Algorithm in ProteinPilot ${ }^{\text {twa }}$ assigned one protein the best confidence possible (unused score) among protein isoforms, which enabled protein subset differentiation, as well the suppression of false positives for protein-grouping analysis [55]. The results were therefore based on protein group identifications presented as protein identifications (IDs).

In the present set of experiments, proteins were identified by using peptide signatures to search custom-built protein sequence databases. Protein ID confidence was determined by the number of proteins that were assuredly accepted as correct, having been identified as described elsewhere [56, 57]. Overall, a total of 267 confident and unique protein groups were identified using ProteinPilot ${ }^{\text {tw }}$ by searching a composite Ovis aries,

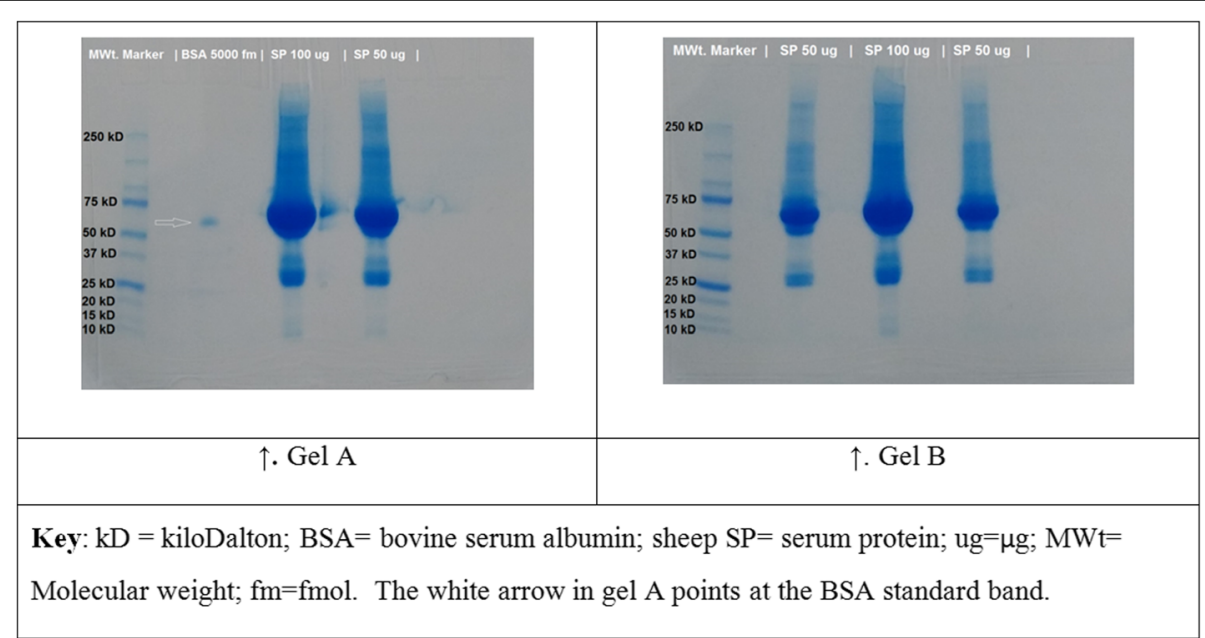

Fig. 2 Coomassie-stained 1D SDS-PAGE gels used in the second in-gel digestion. Fractions of acetone precipitated serum protein samples from a healthy sheep were used. One well in Gel A was loaded with BSA standard (arrow), and two other wells were loaded with $100 \mu \mathrm{g}$ and $50 \mu \mathrm{g}$ of protein each. Three wells in Gel B were loaded with $50 \mu \mathrm{g}, 100 \mu \mathrm{g}$ and $50 \mu \mathrm{g}$ each of protein 


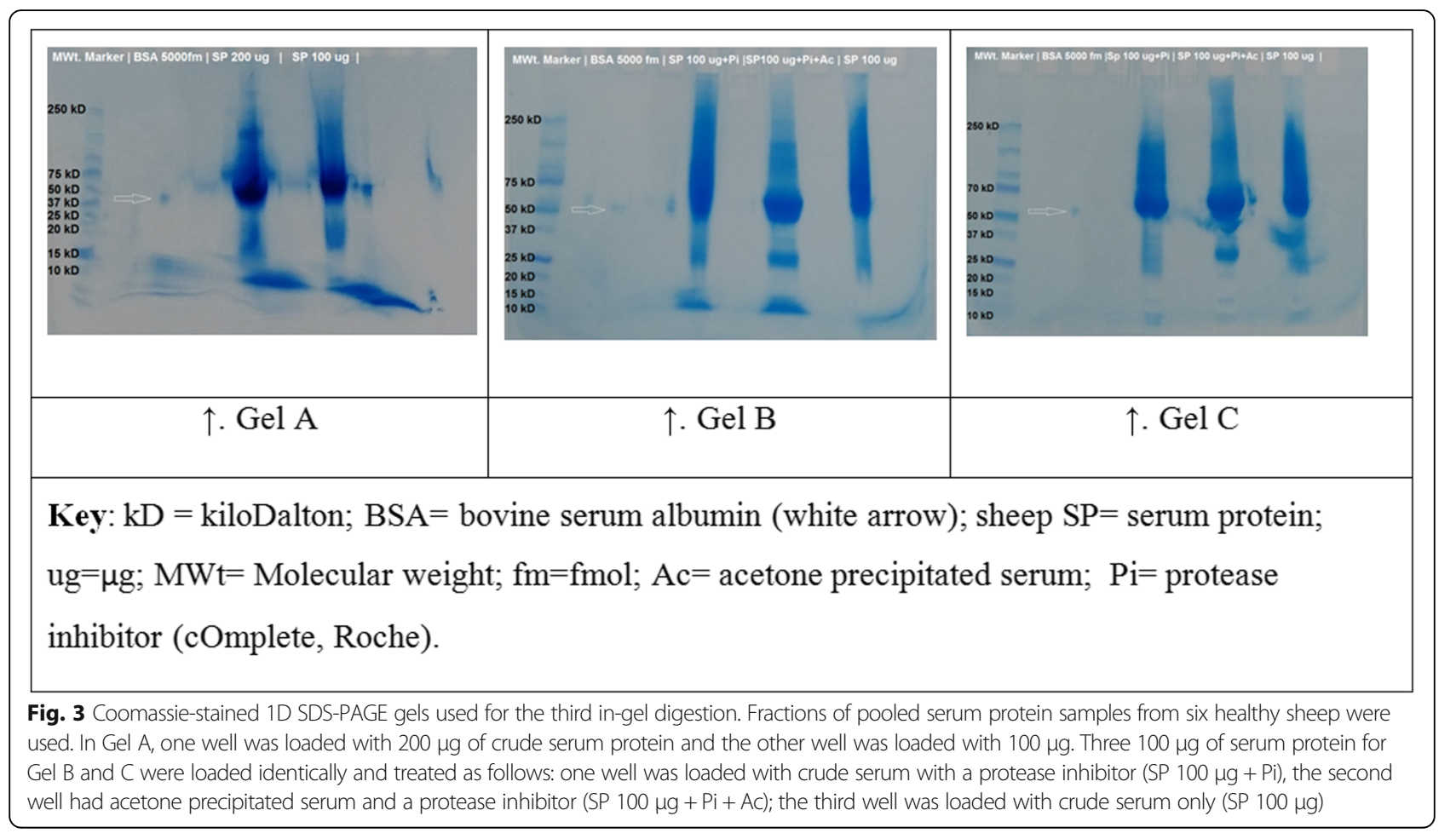

Bos taurus and Capra hircus UniProtKB database after combining all the three in-gel digestion workflows (first, second and third in-gel digestions) from a total quantity of $1,284 \mu \mathrm{g}$ of serum protein obtained from six healthy sheep. The UniProtKB entries for the identified proteins are presented in Additional file 2.

\section{In-solution digestion}

A composite ProteinPilot ${ }^{\mathrm{Tn}}$ search of all the three insolution digestion workflow samples comprising of $130 \mu \mathrm{g}$ of serum protein yielded a total of 102 protein IDs. The UniProtKB entries for these proteins are presented in Additional file 2.

A comparison between the protein identification list derived from combined first, second and third ingel digestion (in-gel digestion workflow) and that of combined first, second and third in-solution digestion (in-solution digestion workflow) in BioVenn Software [51] is presented in Fig. 4. The UniProtKB entries of the 17 proteins that were exclusive to the in-solution digestion workflow (i.e. proteins were not detected by in-gel workflow) are A0A0F6QNP7, W5PSQ7, W5QH45, W5NQW9, G5E604, W5PZF0, W5NWX6, Q1KZF3, W5PJZ2, W5QDP8, W5PDR7, W5PN97, W5PXI6, F1N3Q7, C6ZP49, G3N346 and Q3SYR8.

A combined ProteinPilot ${ }^{\text {tix }}$ search of the pilot data from one sheep and the additional data from five sheep for both in-gel and in-solution digestion workflows using a composite Ovis aries, Bos taurus and Capra hircus protein sequence database yielded an overall outcome of 274 protein IDs. The details of these protein IDs and their peptide sequences are presented in table format in Additional file 2. Based on comparison with previous studies and protein database resources $[10,14,15,24$, $25,58-67]$, a table was drawn from the preceding references listing the details of 67 known, 207 novel and 83 disease-associated serum proteins identified is presented as Additional file 3. The known proteins are those that

Table 1 The number of proteins identified by ProteinPilot ${ }^{\mathrm{TM}}$ Software from in-gel and in-solution digestion of healthy sheep serum samples by searching a composite Ovis aries, Bos taurus and Capra hircus protein sequence database

\begin{tabular}{|c|c|c|c|c|c|c|}
\hline \multirow{2}{*}{$\frac{\text { Experiment } \rightarrow}{\text { Digestion type }}$} & \multicolumn{2}{|c|}{ First digestion } & \multicolumn{2}{|c|}{ Second digestion } & \multicolumn{2}{|c|}{ Third digestion } \\
\hline & In-gel & In-sol & In-gel & In-sol & In-gel & In-sol \\
\hline Serum protein source & Ac & $A C$ & Ac & Crude & Ac + Crude & Crude \\
\hline Total quantity of protein analysed & $34 \mu \mathrm{g}$ & $10 \mu \mathrm{g}$ & $350 \mu \mathrm{g}$ & $20 \mu \mathrm{g}$ & $900 \mu \mathrm{g}$ & $100 \mu \mathrm{g}$ \\
\hline Number of protein IDs & 120 & 25 & 241 & 100 & 182 & 32 \\
\hline
\end{tabular}

Key: In-sol In-solution; Ac Acetone precipitated; IDs Identifications 


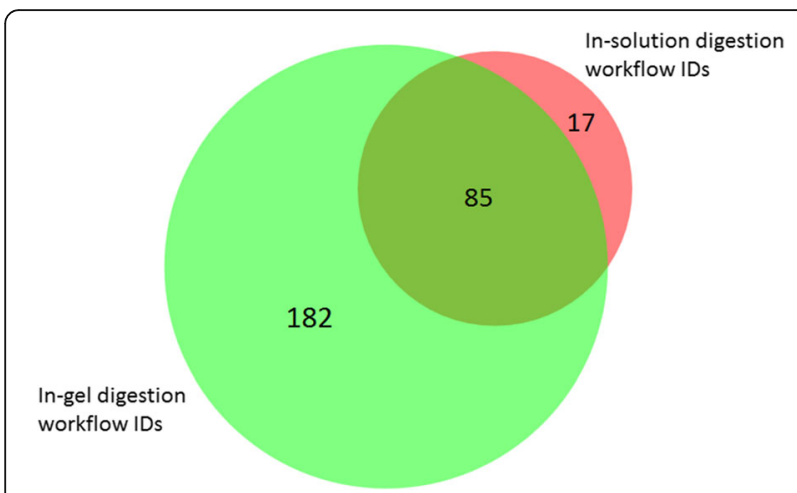

Fig. 4 Comparison of lists of protein identifications (IDs) derived from in-solution versus in-gel digestion using BioVenn Software [51]. Proteins were identified by searching a composite database of Bos taurus, ovis aries and Capra hircus using ProteinPilot ${ }^{\text {TM }}$ Software. Only 17 protein IDs were exclusive to in-solution workflow compared to 182 protein IDs exclusive to in-gel workflow

have been cited in the literature and also have a confirmed status in UniProtKB. Novel proteins constitute those that previously appeared as predicted and proteins that had hitherto been inferred by homology. Diseaseassociated proteins refer to proteins that are expressed or alter during pathology in sheep and other species.

\section{Combined protein identifications from 1D SDS-PAGE and in-solution digestion of serum using ProteinPilot ${ }^{\mathrm{TM}}$ and Mascot database search engines and PeptideShaker search}

Protein yields of a composite search of all the sample data from the three workflows (first, second and third in-gel and in-solution digestion) using a sheep-only UniProtKB database optimised for PeptideShaker Software were as follows: ProteinPilot ${ }^{\mathrm{tm}}$ : 245 IDs and Mascot: 379 IDs. A secondary analysis using PeptideShaker of this same entire dataset yielded 133 IDs (1\% FDR and $\geq 2$ unique validated peptides). The details of these protein IDs are provided in Additional file 4. Again, based on comparison with previous studies and protein database resources [10,14, 15, 24, 25, 58-67], and using the 379 Mascot protein IDs, a table was drawn from the preceding references to list the details of 77 known, 302 novel and 83 disease-associated serum proteins identified using this sheep only database in Additional file 5 .

The 379 protein IDs from Mascot search were used as a benchmark for further downstream analysis. Every sheep protein ID made in Mascot was mapped to a distinct gene. Of all the 379 protein IDs made by searching the sheeponly UniProtKB database, only 74 proteins had been annotated based on sequence similarity to other species, whilst 305 proteins were uncharacterised. Of the 74 annotated proteins, only annexin A2 (P14639), serum albumin (P12303), transthyretin (B3SV56), nuclear receptor subfamily 1 group D member 1 (A2SW69) and insulinlike growth factor-binding protein $2 \mathrm{a}(\mathrm{Q} 29400)$ had been reviewed and therefore included in the Swiss-Prot subset of UniProtKB. The unreviewed, but named proteins included apolipoprotein E, fibulin-1, angiotensinogen, monocyte differentiation antigen CD14, plasminogen, pentaxin (pentraxin), alpha-1-antitrypsin transcript variant 1, histone H2B, alpha-1-acid glycoprotein, amine oxidase, beta-A globin chain, thyroxine-binding globulin, alpha-2HS-glycoprotein, C-X-C motif chemokine, histone H3, coagulation factor IX, histone $\mathrm{H} 4$, factor $\mathrm{H}$, prothrombin, clusterin, L-lactate dehydrogenase, cGMP-dependent protein kinase, antithrombin-III, gelsolin isoform b, ceruloplasmin, $\mathrm{VH}$ region chain, conglutinin 1, DNA polymerase, proteasome subunit alpha type, tubulin beta chain, proteasome subunit alpha type, proteasome subunit alpha type, fibrinogen alpha chain, aspartate aminotransferase, phosphodiesterase, chitinase-3-like protein 1 , superoxide dismutase $[\mathrm{Cu}-\mathrm{Zn}]$, uricase, glyceraldehyde-3-phosphate dehydrogenase, carbonic anhydrase 2, adiponectin, olfactory receptor, histone $\mathrm{H} 2 \mathrm{~A}$, alpha-mannosidase, centromere protein $\mathrm{C}$, importin subunit alpha, 14-3-3 protein sigma, AP complex subunit beta, carboxypeptidase, oxysterol-binding protein, growth hormone receptor variant $\mathrm{H}$, condensin complex subunit 2, large tumour suppressor-like 1 protein,protein-tyrosine-phosphatase, peptidyl-prolyl cis-trans isomerase (PPIase), proteasome subunit alpha type, dipeptidase, proteasome subunit beta type, tubulin alpha chain, proteasome subunit alpha type, fructose-1,6-bisphosphatase 1, polypeptide $\mathrm{N}$-acetylgalactosaminyltransferase, arginase, adenylyl cyclase-associated protein, protein-serine/threonine kinase, transaldolase, MHC class II antigen, glutathione peroxidase and corneodesmosome protein.

\section{Gene ontology (GO) - term analysis of proteins identified in serum of healthy sheep}

The 379 proteins identified by a composite Mascot search of the first, second and third in-gel and insolution digestion of serum proteins from healthy sheep were subjected to gene ontology (GO) analysis using Protein ANalysis THrough Evolutionary Relationships (PANTHER) classification tool [68]. In the PANTHER tool, the gene entries were analysed by aligning them to Bos taurus as the closest organism analogous to sheep because Ovis aries entries were not available. The PANTHER analysis resulted into 349 bovine aligned gene entries listed in Additional file 6.

The results of GO-term analysis of molecular function, biological process, cellular component, protein class and pathway analysis of the detected proteins are provided in Fig. 5. Looking at the molecular function domain of the proteins alone based on the GO term results (Fig. 5a), catalytic activity was dominant of the 264 function hits. 


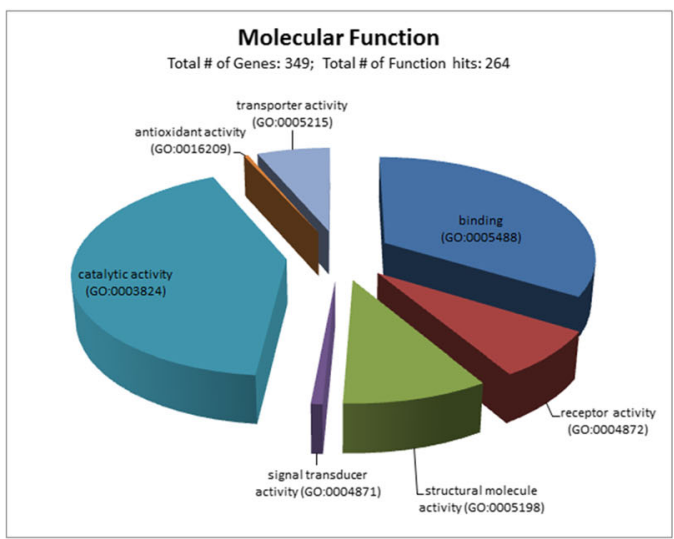

A

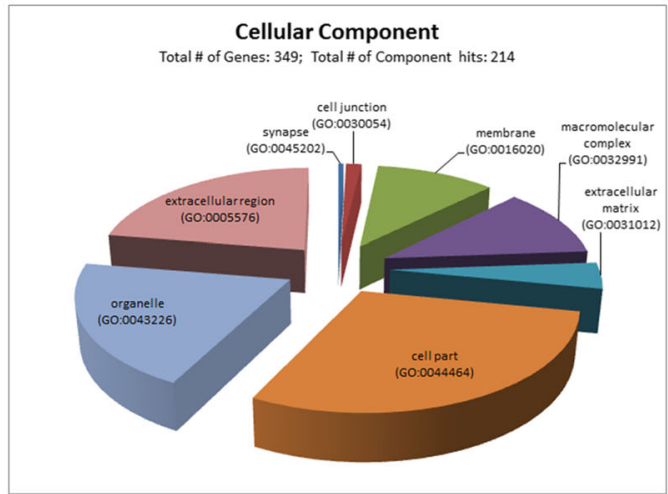

C

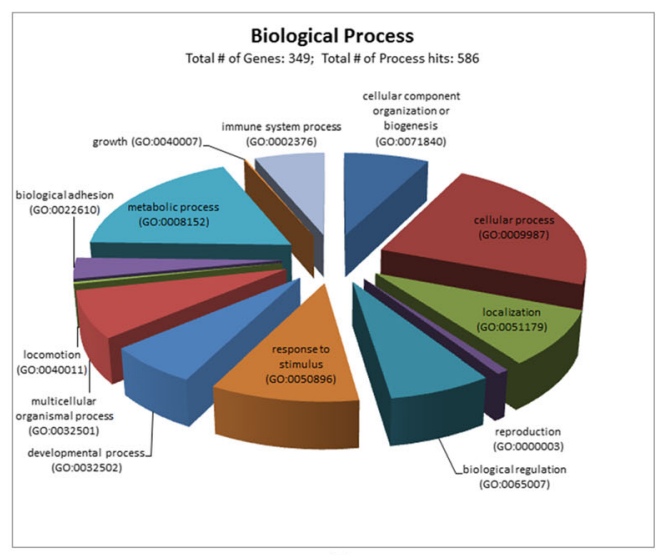

B

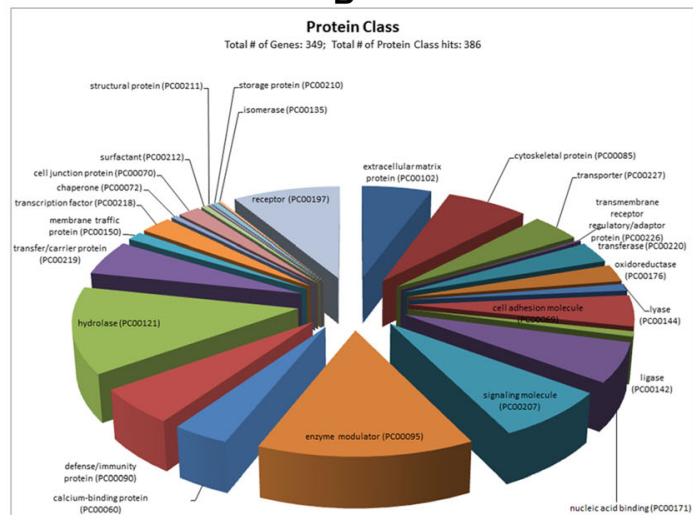

D

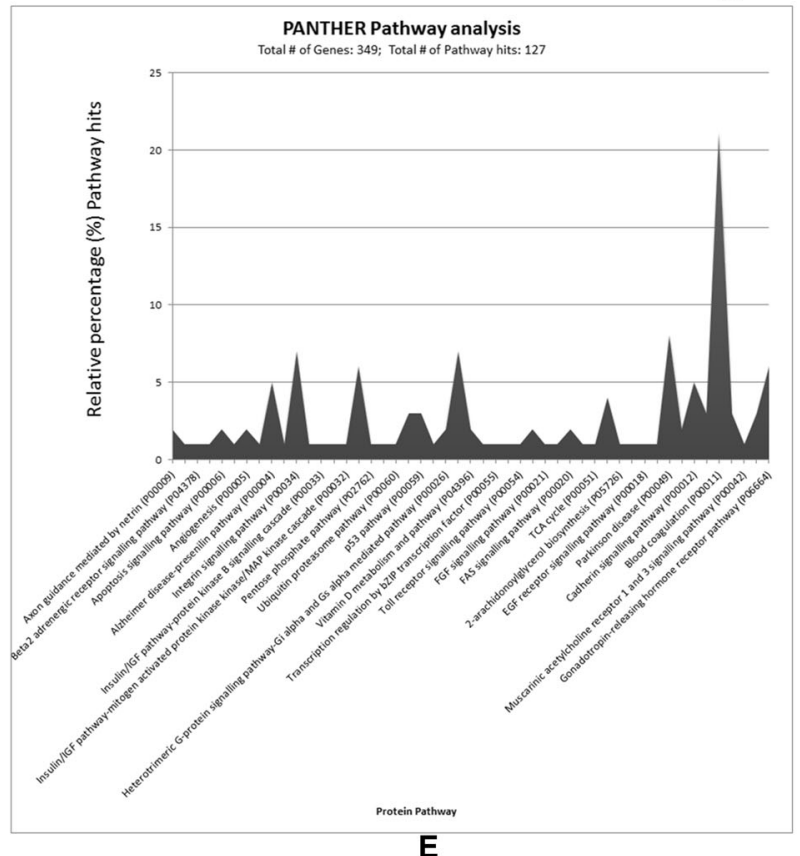

E

Fig. 5 (See legend on next page.) 


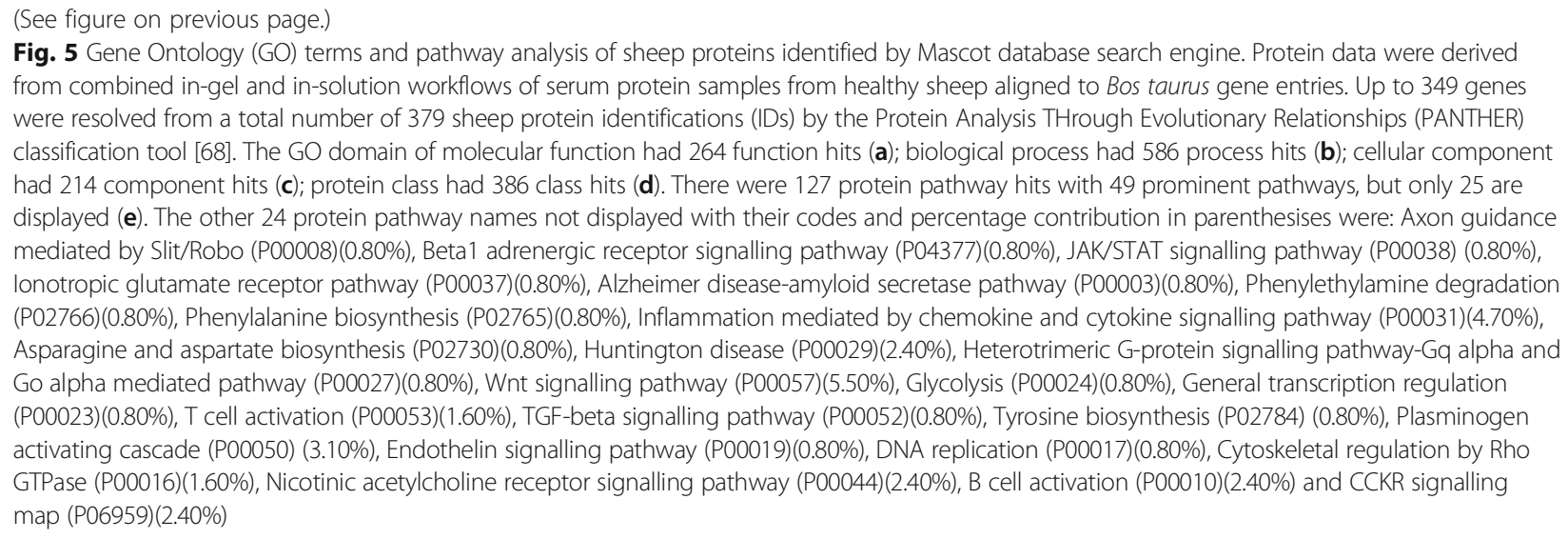

From the protein IDs that had names, at least 27 of them were specifically classified as enzymes from protein database searches. It is evident from these results that there is a hierarchy in the biological processes of the 586 process hits (Fig. 5b). The cellular component GO domain (Fig. 5c) for serum from healthy sheep had 214 hits in total. The protein class GO domain (Fig. 5d) had 386 class hits, with enzyme modulation topping the list. Among the 49 prominent protein pathways that were displayed in PANTHER from the analysed genes, 14 were represented by over $3.0 \%$ contribution to the revealed pathway pool (Fig. 5e).

\section{Discussion}

This study reports the development of a proteomics baseline profile of healthy sheep serum by analysing peptides derived from in-solution digestion and 1D SDSPAGE using nanoLC-nanoESI-MS/MS. The major outcome was that 379 proteins were identified, compared for example to 42 proteins from serum of sheep with mild respiratory disease during peripartum period [10] and a single protein (serum amyloid A) in sheep with scrapie [15]. Both of these cited earlier sheep studies used two dimensional (2-DE) surface enhanced laser desorption/ionisation time of flight mass spectrometry (SELDI-TOF MS) and LC-MS/MS. In species other than sheep, 490 proteins were identified in human sera using multidimensional separation coupled with MS [2], while 340 low molecular weight proteins were identified in human sera using SELDI-TOF MS analysis and LC-MS/MS [69]. There is also a report that assessed three different lots of foetal bovine serum by NanoLC-MS/MS analysis in which 79, 90, and 91 proteins were identified [70]. The preceding study recognised that there is variability in the protein content of different lots of foetal bovine serum - a commonly used growth medium for cell cultures, which affects the consistency of cell growth. The lot with a higher number of protein IDs was associated with higher cell growth rate [70]. Identification of these proteins is important clinically to determining health or altered physiology, such as stress [10].

The use of 1D SDS-PAGE in this study facilitated serum protein samples to be fractionated to reduce protein complexity prior to nanoLC-nanoESI-MS/MS analysis [71]. The first in-gel digestion experiment enabled the determination of the quantity of protein from samples and the amount of the BSA standard that needed to be loaded onto the gel to ensure that protein bands were visible and clearly defined (Fig. 1). Loading a larger quantity of protein onto the gel was necessary to discover as many proteins as possible using DDA [72]. However, the $2 \mu \mathrm{g}$ lane yielded 41 protein IDs in the first in-gel digestion (Fig. 1), while the $10 \mu$ g-lane yielded 20 protein IDs and the $22 \mu \mathrm{g}$ lane yielded 121 protein IDs. The $10 \mu \mathrm{g}$ lane was analysed initially and the $2 \mu \mathrm{g}$ and $22 \mu \mathrm{g}$ lanes were analysed 6 weeks later once the extractions had been optimised and the instrument tuned.

The second in-gel digestion (Fig. 2) increased the protein coverage by loading more protein into the gel wells using a fraction of the acetone precipitated serum sample used in the $1^{\text {st }}$ in-gel digestion. The $100 \mu \mathrm{g}$ ( 2 replicates) and $50 \mu \mathrm{g}$ (3 replicates) protein loads in the $2^{\text {nd }}$ ingel digestion workflow yielded comparable numbers of protein IDs for each of the loaded quantity of protein. This suggests that reproducibility of the amount of protein loaded into the gel lanes had been achieved [71]. The second in-gel digestion was an improvement of the 1st in-gel digestion by having replicate and having increased quantities of loaded protein per lane, using the same serum sample of 1st in-gel digestion from Sheep ID 473.

The 1D SDS-PAGE preparation of one gel in the third in-gel digestion had a number of visual artefacts (Fig. 3). The distortion in the $10-15 \mathrm{kD}$ region of Gel A could have been attributed to a defect in the gel possibly due to inconsistency in gel polymerisation creating artefact bands [35], overloading and/or the presence of a pocket between the gel and the cassette housing that allowed the protein samples to leak out the gel [73]. This could 
have also contributed to the low number of protein yields made from this gel $(200 \mu \mathrm{g}$ : 40 protein IDs; $100 \mu \mathrm{g}$ : 38 protein IDs), compared to the $100 \mu \mathrm{g} \times 2$ lanes in Gels B and C that yielded 114 protein IDs [see Additional file 2]. A couple of variables were also introduced in this experiment, in addition to the quantity of proteins loaded on to the gel wells as planned. The analysis of fractionated crude serum that had a protease inhibitor (cOmplete, Roche) yielded a higher number of protein IDs (162 IDs), compared to the acetone precipitated sample that also had the protease inhibitor (143 IDs). This suggests that a considerable number of proteins were present in the acetone precipitation supernatant that was discarded. The discardment of the supernatant from acetone precipitation is a routine practice during generic or universal sample preparation for proteomic analysis [74].

As for the in-solution digestion workflow, the number of protein identifications from analysing $100 \mu \mathrm{g}$ of crude serum protein was low when compared with $20 \mu \mathrm{g}$. The sample for the first in-solution digestion using $10 \mu \mathrm{g}$ of acetone precipitated serum that was drawn from one healthy pilot sheep (Sheep ID 473) yielded only 25 protein IDs. This sample was prepared and analysed at the same time as the $10 \mu \mathrm{g}$ sample of the first in-gel digestion discussed earlier. Protein detection was therefore likely to have been affected by unoptimised experimental processes at the time prior to running on the MS instrument. The second in-solution digestion using $20 \mu \mathrm{g}$ of crude serum from the same sheep yielded 100 protein IDs. This result was considered substantial, as the number of protein IDs was comparable to those of other studies [10, 75-81]. Unexpectedly however, the third insolution that utilised $100 \mu \mathrm{g}$ of pooled crude serum from six sheep under the same experimental conditions yielded only 32 IDs. It is thought that this result was possibly due to the inhibition of trypsin by the presence of intravenous agents in the pooled sample from the anaesthetic cocktail used to anaesthetise the sheep, as this was not the case with the pilot sheep sample in which the sheep was not anaesthetised during sample collection.

BioVenn Software [51] was utilised for visualisation of the data presented in Fig. 4. This tool enabled the comparison of a protein identification list derived from ingel digestion with that from in-solution digestion by displaying the data in an area-proportional Venn diagram. It showed protein IDs that were exclusive to in-solution and in-gel, and those common between the two digestions. The composite in-solution digestion workflow yielded 102 protein IDs. Of the 17 protein IDs that were exclusive to in-solution digestion workflow, five were mapped to the ox, two to the goat and the remaining 10 IDs were for sheep. Despite having known genes, the vast majority of the identified proteins were either uncharacterised or unreviewed in UniProtKB. Another interesting observation was that the combined list of 284 protein IDs from in-gel and in-solution digestion displayed in BioVenn Software was marginally higher than the 274. IDs from a composite ProteinPilot ${ }^{\mathrm{m}}$ search of the same datasets. It is likely that the subsequent composite ProteinPilot ${ }^{\text {tix }}$ search helped to further group proteins, thereby improving the confidence of protein IDs by minimising false protein identifications - a known challenge when searching a multi-species protein database to identify proteins.

A combined search of the first, second and third in-gel and in-solution digestion datasets using a sheep-only database yielded 245 protein IDs in ProteinPilot ${ }^{\text {Tix }}$ ( $c f 274$ protein IDs using the composite database of the ox, goat and sheep) and Mascot search yielded 379 IDs. The PeptideShaker validation search yielded 133 protein IDs. The comparatively low number of protein IDs made by PeptideShaker is because the protein entries were identified using validated unique peptides - a feature that is not obvious in either ProteinPilot ${ }^{\mathrm{Tu}}$ or Mascot, whose protein ID entries were only based on at least two highscoring peptides per protein, on the assumption that the peptides were unique to the protein.

The results from Mascot search were embraced and utilised for further analysis because this software platform is widely used by the proteomics community and it is considered the industry standard, as it implements a vast array of applications necessary for protein identification [82]. As of September, 2016, the 379 protein IDs complete with UniProtKB accessions was probably the highest number of sheep serum proteins to date using nanoLC-nanoESI-MS/MS. Of these protein IDs, only 74 were named in UniProtKB, whilst the vast majority (305) were yet to be characterised. This study can therefore be considered the first to provide a comprehensive MS/MS protein sequence data of serum proteins of normal sheep and by contributing to the efforts of annotating genes and charactering sheep proteins. Despite most of the proteins not being characterised in UniProtKB, their mapping to known genes and the available mass spectrometry-derived peptide sequence data alongside verification on more than one software platforms, constitute strong supportive evidence that the identified proteins do exist. The downside of the Mascot search is that it does not provide a user-friendly protein sequence output that can be readily tabulated as in the case of ProteinPilot $^{\text {tm }}$ IDs. For this reason, only protein names and UniProtKB entries were utilised mostly for the purposes the present study.

Regarding GO-term analysis, the significance of many of the enzymes that dominated catalytic activity in the molecular function domain (Fig. 5 a), remains to be 
documented in sheep, but the functions of some are known. For example, adenylyl cyclase-associated protein regulates cofilin function, actin cytoskeleton and cell adhesion [83]. Alpha-mannosidase participates in glycoprotein synthesis and endoplasmic reticulum quality control [84]. It has been reported to be downregulated in locoweed (Oxytropis sericea) in sheep $[85,86]$, for example. The functions of other identified enzymes that were drawn from [24, 87-116] are provided in Additional file 7.

Serum samples of healthy adult female Merino sheep were utilised for this study. It is quite possible that a relatively low representation of the growth process domain in the biological process GO-term was because serum samples were derived from adult sheep. Also, the cellular component fractions could possibly vary depending on the physiological status of the sheep - which remains yet to be determined and documented. It can be argued that hormonal changes and the influence of age contribute to observations of serum proteome profiles and this should be accounted for. For instance, studies in sheep have shown that there is a diurnal variation metabolic and stress-responsive hormones [117].

In the present study, there were mechanisms in place to mitigate the effects of stress on the laboratory sheep. The sheep were reared together and acclimatised to their housing and handling by people as a standard management practice prior to blood sampling [33, 118]. Also, there was no variation in calorie intake because feed was supplemented as required $[33,118]$ in order to mitigate the well-established phenomenon of seasonal weight loss - a well-established major nutritional stress factor in sheep [119]. During agistment, there were wethers that belonged to other experiments of the research group, but there were no entire males to cause 'ram effect' that could have caused surges in reproductive hormones [120], for example. Nevertheless, gonadotropic activity would have occurred naturally in the ewes to cause hormonal changes [121], perhaps even with a synchronised hypothalamicpituitary-ovarian axis in all the ewes, as this phenomenon is known to occur naturally [122]. All the sheep were approximately 2 years old and were therefore, practically in the same metabolic and physiological state during blood sampling. Also, the sheep belonged to an ovine model of blood transfusion [123], so most preventable adverse attributes had been catered for.

The fundamental 'method' for pulling proteins from the liquid fraction of blood using the explored approach is already well-developed in itself, but this study went beyond this to develop a tailored platform, comprising a series of refined methods, to give this practical application. The knowledge from this prototype study has illuminated a considerable number of bovine-aligned gene entries associated with protein pathways that can be valuably exploited by animal model studies using sheep serum as their analyte. A downside of the present study is that no males were represented in the dataset. Future studies should take into account hormonal changes, be gender and age inclusive in order to capture broad aspects of the proteome that could have been missed in this report.

\section{Conclusion}

This study has demonstrated for the first time that it is feasible to identify several hundred sheep serum proteins using nanoLC-nanoESI-MS/MS. By utilising the PANTHER tool, this serum-derived prototype of the ovine circulating acellular proteome revealed association of 349 genes with 127 protein pathway hits. When used with protein quantitative data, these findings have the potential to be applied as the foundation for establishing the baseline normal ovine serum proteome that could be used in comparison with samples from sick sheep. The peptide spectral data here also are a contribution towards a library that can be applied for targeted proteomics approaches, such as sequential acquisition of all theoretical fragrant mass spectra (SWATH)-MS to fulfil proteogenomics study efforts on sheep in future.

\section{Additional files}

Additional file 1: One-dimensional sodium dodecyl sulfate polyacrylamide gel electrophoresis (1D SDS-PAGE). In-gel fractionation (1D SDS-PAGE) of sheep serum protein samples. (DOCX $24 \mathrm{~kb}$ )

Additional file 2: Protein identification results from using Protein Pilot $^{\mathrm{TM}}$ to search a composite (Bos taurus, Ovis aries and Carpra hircus) UniProtKB protein sequence database of serum samples derived from the first, second and third in-gel and in-solution digestion with a results quality of FDR $\leq 1 \%$; $\geq 2$ peptides for the highest scoring member of the protein group to be considered confidently identified. Each tab contains a list of protein IDs based on the quantity of protein loaded $(\mu \mathrm{g})$, digestion workflow or sample conditions as follows: 1st_In-gel_digestion_2 $\mu \mathrm{g}=$ first ingel $(2 \mu \mathrm{g}) ; 1$ st_In-gel_digestion_10 $\mu \mathrm{g}=$ first in-gel $(10 \mu \mathrm{g}) ; 1 \mathrm{st} \_\mathrm{In}$ gel_digestion_22 $\mu \mathrm{g}=$ first in-gel $(22 \mu \mathrm{g})$; All_1st_In-gel_digestion_IDs = all first in-gel samples; 2nd_In-gel_digestion_100 $\mu \mathrm{gGel} A=$ second in-gel digestion of Gel A $(100 \mu \mathrm{g}) ; 2$ 2nd_In-gel_digestion_50 $\mu \mathrm{gGel} A$ = second in-gel digestion of Gel A $(50 \mu \mathrm{g})$; 2nd_In-gel_digestion_50 $\mu \mathrm{gGelB}=$ second in-gel digestion of Gel B $(50 \mu \mathrm{g})$; 2nd In-gel digestion 100 $\mathrm{\mu g} \mathrm{GelB}=$ second

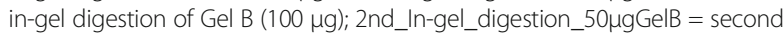
in-gel digestion of Gel B $(50 \mu \mathrm{g})$; All_2nd_In-gel_digestion_IDs = composite of all second in-gel digestion samples; 3rd_In-gel_digestion_200 $\mathrm{gg}=$ crude serum protein of the third in-gel digestion $(200 \mu \mathrm{g})$; 3rd_In-gel_digestion_100 $\mu \mathrm{g}=$ crude serum protein of the third in-gel digestion $(100 \mu \mathrm{g})$; $3 r d$ In-gel_digest_100 $\mu \mathrm{g} \times 2 \mathrm{Crudel}=$ crude serum protein with a protease inhibitor (Roche) of the third in-gel digestion $(100 \mu \mathrm{g} \times 2)$; 3rd_Ingel_digest_100 $\mu \mathrm{g} \times 2$ AcePPT $=$ acetone precipitated serum protein without a protease inhibitor of the third in-gel digestion $(100 \mu \mathrm{g} \times$

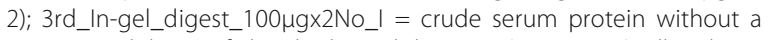
protease inhibitor of the third in-gel digestion $(100 \mu \mathrm{g} \times 2)$; All_3rd Ingel_Digestion_IDs = composite of all third in-gel digestion samples; All_Ingel_digestion_IDs = all in-gel digestion workflow; 1st_In-solution_ digestion_10 $\mu \mathrm{g}=$ acetone precipitated serum protein from the first in-solution digestion $(10 \mu \mathrm{g})$; 2nd_In-solution_digestion_20 $\mu \mathrm{g}$ = crude serum protein from the second in-solution digestion (20 $\mu \mathrm{g})$; $3 r d \_I n-s o l u t i o n \_d i g e s t i o n \_100 \mu \mathrm{g}=$ crude serum protein from the third in-solution digestion $(100 \mu \mathrm{g})$; All_In-solution_digestion_IDs $=$ all in-solution workflow samples; All_Proteins + Peptide_Sequences $=274$ 
protein IDs and peptide sequences of the entire in-gel and in-solution digestion experiments. (XLSX $423 \mathrm{~kb}$ )

Additional file 3: Details of known, novel and disease-associated sheep serum proteins identified by ProteinPilot ${ }^{\text {TM }}$ by a searching a composite UniProtKB protein sequence database of Bos taurus, Ovis aries and Capra hircus. This 3-sheet Microsoft Excel file contains the details of 67 known (Known_Proteins_in_Literature), 207 novel (Novel_Proteins) and 83 disease-associated (Disease-Associated_Proteins) serum proteins identified using this composite database. The known proteins are those that have been cited in the literature and also have a confirmed status in UniProtKB. Novel proteins constitute those that previously appeared as predicted and proteins that had hitherto been inferred by homology. Disease-associated proteins refer to proteins that are expressed or alter during pathology in sheep and other species. (XLSX $161 \mathrm{~kb}$ )

Additional file 4: Protein identifications by ProteinPilot ${ }^{\mathrm{TM}}$, Mascot and PeptideShaker search engines from searching a composite of the first, second and third digestions sheep serum protein data using an Ovis aries only UniProtKB protein sequence database. This 3-sheet Microsoft $\mathrm{Exce}^{\oplus \mathrm{TM}}$ file contains the details of protein identifications of a composite search of all the sample data from the three workflows (first, second and third in-gel and in-solution digestion) using an Ovis aries only UniProtKB database optimised for PeptideShaker Software. The tab details are as follows: ProteinPilot_IDs_+_Sequences $=245$ ProteinPilot ${ }^{\text {TM }}$ protein IDs complete with peptide sequences; Mascot_IDs = 379 Mascot protein IDs and PeptideShaker_IDs = 133 PeptideShaker protein IDs. (XLSX $170 \mathrm{~kb}$ )

Additional file 5: Details of known, novel and disease-associated sheep serum proteins identified by Mascot from searching a composite of the first, second and third digestions sheep serum protein data using an Ovis aries UniProtKB protein sequence database. This 3-sheet Microsoft Excel file contains the details of 77 known (Known Proteins in Literature), 301 novel (Novel_Proteins) and 83 disease-associated (Disease-Associated_Proteins) serum proteins identified using an Ovis aries UniProtKB database. (XLSX $14 \mathrm{~kb}$ )

Additional file 6: List of 349 bovine aligned gene entries derived from inputting 379 Ovis aries protein data in the PANTHER classification tool. This 2-sheet Microsoft Excel file contains the list of 349 bovine aligned gene entries (349_Bovine_aligned_gene_entries) derived from analysing gene information of 379 serum proteins identified by Mascot (Input of 379 Ovine_Mascot_IDs) using an Ovis aries UniProtKB database. (XLSX 49 kb)

Additional file 7: Functions of dominant enzymes identified in healthy sheep serum. The functions of enzymes identified in healthy sheep serum that dominated catalytic activity in the molecular function domain after gene ontology analysis. (DOCX $67 \mathrm{~kb}$ )

\section{Abbreviations}

1D SDS-PAGE: One-dimensional sodium dodecyl sulfate polyacrylamide gel electrophoresis; ACN: Acetonitrile; ARCBS: Australian Red Cross Blood Service; BCA: Bicinchoninic acid assay; BSA: Bovine serum albumin; CARF: Central Analytical Facility; DDA: Data dependent acquisition; DNA: Deoxyribonucleic acid; DTT: Dithiothreitol; EDTA: Ethylenediaminetetraacetic acid; ESI-QUADTOF: Electrospray ionisation quadrupole time-of-flight; FA: Formic acid; FDR: False discovery rate; GO: Gene ontology; IAM: lodoacetamide; ID: Identification; LC: Liquid chromatography; MGRF: Molecular Genetics Research Facility; MHC: Major histocompatibility complex; MS: Mass spectrometry; MS/MS: tandem mass spectrometry; nanoLC-nanoESI-MS/ MS: nano liquid chromatography nano electrospray ionisation tandem mass spectrometry; NCBI: National Center for Biotechnology Information; PANTHER: Protein analysis through evolutionary relationships: PRIDE: Proteomics identifications; QUT: Queensland University of Technology; RT: Room temperature; SP: Serum protein; SWATH: Sequential acquisition of all theoretical fragrant mass spectra; TEMED: Tetramethylethylenediamine; TFA: Trifluoroacetic acid; TOF: Time-of-flight; UQ: The University of Queensland

\section{Acknowledgements}

Thank you to Dr John-Paul Tung and the Australian Red Cross Blood Service in Brisbane for making available the primary samples used in this manuscript under Agreement No. 15-03QLD-19.

\section{Funding}

This work was undertaken as part of SC's PhD which was financially supported from personal means, an Australian Postgraduate Award scholarship and $\mathrm{H}$. George Osborne Research Scholarship, both of which were through The University of Queensland. All the facilities for the experimental work were funded by a collaborative arrangement with Queensland University of Technology Central Analytical Research Facility (QUT-CARF).

\section{Availability of data and materials}

The mass spectrometry data that support the findings of this study along with the identification results were deposited to ProteomeXchange Consortium [52] via the proteomics identifications (PRIDE) partner repository [53] with the dataset identifiers PXD004989 and 10.6019/PXD004989 with the following data access details: Reviewer account details: Username: reviewer99399@ebi.ac.uk; Password: QBFFTGzl.

\section{Authors' contributions}

SC originated the concept of the study and conducted the experiments with PS. SC, RG and PS developed the methods and analytical procedures of the samples. SC drafted the manuscript, and PCM and SRK made substantial revisions. All authors have read the final manuscript.

\section{Competing interests}

The authors declare that they have no competing interests.

\section{Consent for publication}

Not applicable.

\section{Ethics approval and consent to participate}

This study was conducted in accordance with the Australian Code of Practice for the Care and Use of Animals for Scientific Purposes [124]. Tissue from live animal experiments had animal ethics approval obtained from the University Animal Ethics Committee of Queensland University of Technology (QUT) reference 0800000555 , which was ratified by The University of Queensland (UQ).

\section{Publisher's Note}

Springer Nature remains neutral with regard to jurisdictional claims in published maps and institutional affiliations.

\section{Author details}

${ }^{1}$ School of Veterinary Science, The University of Queensland, Gatton, Australia. ${ }^{2}$ Proteomics and Small Molecule Mass Spectrometry, Central Analytical Research Facility, Queensland University of Technology, Brisbane, Australia.

Received: 11 December 2016 Accepted: 2 June 2017

Published online: 10 June 2017

\section{References}

1. Pieper R, Gatlin CL, Makusky AJ, Russo PS, Schatz CR, Miller SS, Su Q, McGrath AM, Estock MA, Parmar PP, et al. The human serum proteome: display of nearly 3700 chromatographically separated protein spots on twodimensional electrophoresis gels and identification of 325 distinct proteins. Proteomics. 2003:3:1345-64.

2. Adkins JN, Varnum SM, Auberry KJ, Moore RJ, Angell NH, Smith RD, Springer $\mathrm{DL}$, Pounds JG. Toward a human blood serum proteome: analysis by multidimensional separation coupled with mass spectrometry. Mol Cell Proteomics. 2002:1:947-55.

3. Kijas JW, Menzies M, Ingham A. Sequence diversity and rates of molecular evolution between sheep and cattle genes. Anim Genet. 2006;37:171-4.

4. Vanselow J, Furbass R, Rehbock F, Klautschek G, Schwerin M. Cattle and sheep use different promoters to direct the expression of the aromatase cytochrome P450 encoding gene, Cyp19, during pregnancy. Domest Anim Endocrinol. 2004;27:99-114.

5. Walters EM, Agca Y, Ganjam V, Evans T. Animal models got you puzzled?: think pig. Ann N Y Acad Sci. 2011;1245:63-4.

6. Wang S, Liu Y, Fang D, Shi S. The miniature pig: a useful large animal model for dental and orofacial research. Oral Dis. 2007;13:530-7.

7. Dehoux JP, Gianello P. The importance of large animal models in transplantation. Front Biosci. 2007;12:4864-80. 
8. Casal M, Haskins M. Large animal models and gene therapy. Eur J Hum Genet. 2005;14:266-72.

9. Schaefer A, Schneeberger Y, Stenzig J, Biermann D, Jelinek M, Reichenspurner H, Eschenhagen T, Ehmke H, Schwoerer AP. A New Animal Model for Investigation of Mechanical Unloading in Hypertrophic and Failing Hearts: Combination of Transverse Aortic Constriction and Heterotopic Heart Transplantation. PLoS One. 2016;11, e0148259.

10. Chiaradia E, Avellini L, Tartaglia M, Gaiti A, Just I, Scoppetta F, Czentnar Z, Pich A. Proteomic evaluation of sheep serum proteins. BMC Vet Res. 2012;8:66,

11. Di Girolamo F, D'Amato A, Lante I, Signore F, Muraca M, Putignani L. Farm animal serum proteomics and impact on human health. Int J Mol Sci. 2014; 15:15396-411.

12. Meling S, Kvalheim OM, Arneberg R, Bardsen K, Hjelle A, Ulvund MJ. Investigation of serum protein profiles in scrapie infected sheep by means of SELDI-TOF-MS and multivariate data analysis. BMC Res Notes. 2013;6:466.

13. Batxelli-Molina I, Salvetat N, Andreoletti O, Guerrier L, Vicat G, Molina F, Mourton-Gilles C. Ovine serum biomarkers of early and late phase scrapie. BMC Vet Res. 2010;6:49.

14. Zhong L, Taylor D, Begg DJ, Whittington RJ. Biomarker discovery for ovine paratuberculosis (Johne's disease) by proteomic serum profiling. Comp Immunol Microbiol Infect Dis. 2011;34:315-26.

15. Sun D, Zhang H, Guo D, Sun A, Wang H. Shotgun Proteomic Analysis of Plasma from Dairy Cattle Suffering from Footrot: Characterization of Potential Disease-Associated Factors. PLoS One. 2013;8:e55973.

16. Bradshaw RA, Burlingame AL, Carr S, Aebersold R. Reporting protein identification data: the next generation of guidelines. Mol Cell Proteomics. 2006:5:787-8.

17. Seymour SL, Farrah T, Binz P-A, Chalkley RJ, Cottrell JS, Searle BC, Tabb DL, Vizcaíno JA, Prieto G, Uszkoreit J, et al. A standardized framing for reporting protein identifications in mzldentML 1.2. Proteomics. 2014;14: 2389-99.

18. Anderson NL, Anderson NG. The human plasma proteome: history, character, and diagnostic prospects. Mol Cell Proteomics. 2002;1:845-67.

19. Omenn GS, States DJ, Adamski M, Blackwell TW, Menon R, Hermjakob H, Apweiler R, Haab BB, Simpson RJ, Eddes JS, et al. Overview of the HUPO Plasma Proteome Project: results from the pilot phase with 35 collaborating laboratories and multiple analytical groups, generating a core dataset of 3020 proteins and a publicly-available database. Proteomics. 2005;5:3226-45.

20. Omenn GS. Plasma Proteomics, The Human Proteome Project, and CancerAssociated Alternative Splice Variant Proteins. Biochim Biophys Acta. 1844; 2014:866-73.

21. States DJ, Omenn GS, Blackwell TW, Fermin D, Eng J, Speicher DW, Hanash SM. Challenges in deriving high-confidence protein identifications from data gathered by a HUPO plasma proteome collaborative study. Nat Biotechnol. 2006;24:333-8.

22. Cai XW, Shedden KA, Yuan SH, Davis MA, Xu LY, Xie CY, Fu XL, Lawrence TS, Lubman DM, Kong FM. Baseline plasma proteomic analysis to identify biomarkers that predict radiation-induced lung toxicity in patients receiving radiation for non-small cell lung cancer. J Thorac Oncol. 2011;6:1073-8.

23. Clement CC, Aphkhazava D, Nieves E, Callaway M, Olszewski W, Rotzschke $\mathrm{O}$, Santambrogio L. Protein expression profiles of human lymph and plasma mapped by 2D-DIGE and 1D SDS-PAGE coupled with nanoLC-ESI-MS/MS bottom-up proteomics. J Proteomics. 2013;78:172-87.

24. Magrane M, Consortium U. UniProt Knowledgebase: a hub of integrated protein data. Database. 2011;2011.

25. Consortium TU. UniProt: a hub for protein information. Nucleic Acids Res. 2015;43:D204-12.

26. Armengaud J, Trapp J, Pible O, Geffard O, Chaumot A, Hartmann EM. Nonmodel organisms, a species endangered by proteogenomics. J Proteomics. 2014;105:5.

27. Trapp J, Geffard O, Imbert G, Gaillard J-C, Davin A-H, Chaumot A, Armengaud J. Proteogenomics of Gammarus fossarum to Document the Reproductive System of Amphipods. Mol Cell Proteomics. 2014;13:3612-25.

28. Nesvizhskii Al. Proteogenomics: concepts, applications and computational strategies. Nat Methods. 2014;11:1114-25.

29. Renuse S, Chaerkady R, Pandey A. Proteogenomics. Proteomics. 2011;11:620-30.

30. Sigdel TK, Sarwal MM. The proteogenomic path towards biomarker discovery. Pediatr Transplant. 2008;12:737-47.

31. Perkins DN, Pappin DJ, Creasy DM, Cottrell JS. Probability-based protein identification by searching sequence databases using mass spectrometry data. Electrophoresis. 1999;20:3551-67.
32. Vaudel M, Burkhart JM, Zahedi RP, Oveland E, Berven FS, Sickmann A, Martens L, Barsnes H. PeptideShaker enables reanalysis of MS-derived proteomics data sets. Nat Biotechnol. 2015;33:22-4.

33. Chemonges S, Shekar K, Tung JP, Dunster KR, Diab S, Platts D, Watts RP, Gregory SD, Foley S, Simonova G, et al. Optimal Management of the Critically III: Anaesthesia, Monitoring, Data Capture, and Point-of-Care Technological Practices in Ovine Models of Critical Care. Biomed Res Int. 2014:2014:468309.

34. Smith PK, Krohn Rl, Hermanson GT, Mallia AK, Gartner FH, Provenzano MD, Fujimoto EK, Goeke NM, Olson BJ, Klenk DC. Measurement of protein using bicinchoninic acid. Anal Biochem. 1985;150:76-85.

35. Laemmli UK. Cleavage of structural proteins during the assembly of the head of bacteriophage T4. Nature. 1970;227:680-5.

36. Schägger $\mathrm{H}$. Electrophoretic isolation of membrane proteins from acrylamide gels. Appl Biochem Biotechnol. 1994;48:185-203.

37. Schägger H. Tricine-SDS-PAGE. Nat Protoc. 2006;1:16-22.

38. Schägger $\mathrm{H}$, von Jagow $\mathrm{G}$. Tricine-sodium dodecyl sulfate-polyacrylamide gel electrophoresis for the separation of proteins in the range from 1 to 100 kDa. Anal Biochem. 1987;166:368-79.

39. Brunelle JL, Green R. One-dimensional SDS-polyacrylamide gel electrophoresis (1D SDS-PAGE). Methods Enzymol. 2014;541:151-9.

40. Herbert B, Galvani M, Hamdan M, Olivieri E, MacCarthy J, Pedersen S, Righetti PG. Reduction of alkylation of proteins in preparation of twodimensional map analysis: Why, when, and how? Electrophoresis. 2001;22: 2046-57.

41. Shevchenko A, Tomas H, Havlis J, Olsen JV, Mann M. In-gel digestion for mass spectrometric characterization of proteins and proteomes. Nat Protocols. 2007;1:2856-60

42. Villén J, Gygi SP. The SCX/IMAC enrichment approach for global phosphorylation analysis by mass spectrometry. Nat Protoc. 2008;3:1630-8.

43. Yu Y, Smith M, Pieper R. A spinnable and automatable StageTip for high throughput peptide desalting and proteomics. 2014

44. Rappsilber J, Mann M, Ishihama Y. Protocol for micro-purification, enrichment, pre-fractionation and storage of peptides for proteomics using StageTips. Nat Protocols. 2007;2:1896-906.

45. Kulak NA, Pichler G, Paron I, Nagaraj N, Mann M. Minimal, encapsulated proteomic-sample processing applied to copy-number estimation in eukaryotic cells. Nat Meth. 2014:11:319-24.

46. Shilov IV, Seymour SL, Patel AA, Loboda A, Tang WH, Keating SP, Hunter CL, Nuwaysir LM, Schaeffer DA. The Paragon Algorithm, a Next Generation Search Engine That Uses Sequence Temperature Values and Feature Probabilities to Identify Peptides from Tandem Mass Spectra. Mol Cell Proteomics. 2007:6:1638-55.

47. Elias JE, Gygi SP. Target-decoy search strategy for mass spectrometry-based proteomics. Methods Mol Biol. 2010;604:55-71.

48. Vaudel M, Breiter D, Beck F, Rahnenfuhrer J, Martens L, Zahedi RP. D-score: a search engine independent MD-score. Proteomics. 2013;13:1036-41.

49. Taus T, Kocher T, Pichler P, Paschke C, Schmidt A, Henrich C, Mechtler K. Universal and confident phosphorylation site localization using phosphoRS. J Proteome Res. 2011;10:5354-62.

50. Barsnes H, Vaudel M, Colaert N, Helsens K, Sickmann A, Berven FS, Martens L. compomics-utilities: an open-source Java library for computational proteomics. BMC Bioinformatics. 2011;12:70.

51. Hulsen T, de Vlieg J, Alkema W. BioVenn - a web application for the comparison and visualization of biological lists using area-proportional Venn diagrams. BMC Genomics. 2008;9:488.

52. Vizcaino JA, Deutsch EW, Wang R, Csordas A, Reisinger F, Rios D, Dianes JA, Sun Z, Farrah T, Bandeira N, et al. ProteomeXchange provides globally coordinated proteomics data submission and dissemination. Nat Biotechnol. 2014;32:223-6.

53. Martens L, Hermjakob H, Jones $P$, Adamski M, Taylor C, States D, Gevaert K, Vandekerckhove J, Apweiler R. PRIDE: the proteomics identifications database. Proteomics. 2005;5:3537-45

54. Zougman A, Mann M, Nagaraj N, Winiewski JR. Universal sample preparation method for proteome analysis. Nat Methods. 2009;6:359-62.

55. Seymour SL, Hunter CJ. ProteinPilot' ${ }^{\text {TM }}$ Software Overview: High Quality, InDepth Protein Identification and Protein Expression Analysis. USA: AB Sciex Pte. Ltd; 2015. p. 1-5.

56. Spivak M, Weston J, Tomazela D, MacCoss MJ, Noble WS. Direct maximization of protein identifications from tandem mass spectra. Mol Cell Proteomics. 2012;1:M111 012161. 
57. States DJ, Omenn GS, Blackwell TW, Fermin D, Eng J, Speicher DW, Hanash SM. Challenges in deriving high-confidence protein identifications from data gathered by a HUPO plasma proteome collaborative study. Nat Biotech. 2006;24:333-8.

58. International Sheep Genomics C, Archibald AL, Cockett NE, Dalrymple BP, Faraut T, Kijas JW, Maddox JF, McEwan JC, Hutton Oddy V, Raadsma HW, et al. The sheep genome reference sequence: a work in progress. Anim Genet. 2010;41:449-53.

59. Bannach O, Birkmann E, Reinartz E, Jaeger K-E, Langeveld JPM, Rohwer RG, Gregori L, Terry LA, Willbold D, Riesner D. Detection of Prion Protein Particles in Blood Plasma of Scrapie Infected Sheep. PLoS One. 2012;7, e36620.

60. Katunguka-Rwakishaya E. Influence of Trypanosoma congolense infection on some blood inorganic and protein constituents in sheep. Rev Elev Med Vet Pays Trop. 1996:49:311-4

61. Meling S, Bardsen K, Ulvund MJ. Presence of an acute phase response in sheep with clinical classical scrapie. BMC Vet Res. 2012;8.

62. Wells B, Innocent GT, Eckersall PD, McCulloch E, Nisbet AJ, Burgess ST. Two major ruminant acute phase proteins, haptoglobin and serum amyloid $\mathrm{A}$, as serum biomarkers during active sheep scab infestation. Vet Res. 2013;44:103.

63. Ersdal C, Jørgensen HJ, Lie Kl. Acute and Chronic Erysipelothrix rhusiopathiae Infection in Lambs. Vet Pathol. 2014;52:635-43.

64. Aytekin I, Aksit H, Sait A, Kaya F, Aksit D, Gokmen M, Baca AU. Evaluation of oxidative stress via total antioxidant status, sialic acid, malondialdehyde and RT-PCR findings in sheep affected with bluetongue. Veterinary Record Open. 2015;2, e000054.

65. Burgess STG, Nunn F, Nath M, Frew D, Wells B, Marr EJ, Huntley JF, McNeilly TN, Nisbet AJ. A recombinant subunit vaccine for the control of ovine psoroptic mange (sheep scab). Vet Res. 2016;47:26.

66. Chemonges S, Tung JP, Fraser JF. Proteogenomics of selective susceptibility to endotoxin using circulating acute phase biomarkers and bioassay development in sheep: a review. Proteome Sci. 2014;12:12.

67. McDonald Cl, Fung YL, Shekar K, Diab SD, Dunster KR, Passmore MR, Foley SR, Simonova G, Platts D, Fraser JF. The impact of acute lung injury, ECMO and transfusion on oxidative stress and plasma selenium levels in an ovine model. J Trace Elem Med Biol. 2015;30:4-10.

68. Mi H, Poudel S, Muruganujan A, Casagrande JT, Thomas PD. PANTHER version 10: expanded protein families and functions, and analysis tools. Nucleic Acids Res. 2016;44:D336-342.

69. Tirumalai RS, Chan KC, Prieto DA, Issaq HJ, Conrads TP, Veenstra TD. Characterization of the Low Molecular Weight Human Serum Proteome. Mol Cell Proteomics. 2003;2:1096-103.

70. Zheng X, Baker H, Hancock WS, Fawaz F, McCaman M, Pungor Jr E. Proteomic analysis for the assessment of different lots of fetal bovine serum as a raw material for cell culture. Part IV. Application of proteomics to the manufacture of biological drugs. Biotechnol Prog. 2006;22:1294-300.

71. Zhang G, Fenyö D, Neubert TA. Use of DNA ladders for reproducible protein fractionation by SDS-PAGE for quantitative proteomics. J Proteome Res. 2008; 7:678-86

72. Gillet LC, Navarro P, Tate S, Rost H, Selevsek N, Reiter L, Bonner R, Aebersold R. Targeted data extraction of the MS/MS spectra generated by dataindependent acquisition: a new concept for consistent and accurate proteome analysis. Mol Cell Proteomics. 2012:11:0111 016717.

73. Gallagher SR. One-dimensional SDS gel electrophoresis of proteins. Curr Protoc Mol Biol 2006, Chapter 10:Unit 10 12A.

74. Wu X, Xiong E, Wang W, Scali M, Cresti M. Universal sample preparation method integrating trichloroacetic acid/acetone precipitation with phenol extraction for crop proteomic analysis. Nat Protocols. 2014;9:362-74.

75. Seth M, Lamont EA, Janagama HK, Widdel A, Vulchanova L, Stabel JR, Waters WR, Palmer MV, Sreevatsan S. Biomarker discovery in subclinical mycobacterial infections of cattle. PLoS One. 2009;4, e5478.

76. Guryca V, Lamerz J, Ducret A, Cutler P. Qualitative improvement and quantitative assessment of $\mathrm{N}$-terminomics. Proteomics. 2012;12:1207-16.

77. Turk R, Piras C, Kovačić M, Samardžija M, Ahmed H, De Canio M, Urbani A, Meštrić ZF, Soggiu A, Bonizzi L, Roncada P. Proteomics of inflammatory and oxidative stress response in cows with subclinical and clinical mastitis. J Proteomics. 2012;75:4412-28.

78. Genini S, Paternoster T, Costa A, Botti S, Luini MV, Caprera A, Giuffra E. Identification of serum proteomic biomarkers for early porcine reproductive and respiratory syndrome (PRRS) infection. Proteome Sci. 2012;10:48.

79. Alonso-Fauste I, Andrés M, Iturralde M, Lampreave F, Gallart J, Álava MA. Proteomic characterization by 2-DE in bovine serum and whey from healthy and mastitis affected farm animals. J Proteomics. 2011;75:3015.
80. Barton C, Beck P, Kay R, Teale P, Roberts J. Multiplexed LC-MS/MS analysis of horse plasma proteins to study doping in sport. Proteomics. 2009;9:3058-65

81. Faulkner S, Elia G, Mullen MP, O'Boyle P, Dunn MJ, Morris D. A comparison of the bovine uterine and plasma proteome using iTRAQ proteomics. Proteomics. 2012;12:2014-23.

82. Deutsch EW. File Formats Commonly Used in Mass Spectrometry Proteomics. Mol Cell Proteomics. 2012;11:1612-21.

83. Zhang H, Ghai P, Wu H, Wang C, Field J, Zhou GL. Mammalian adenylyl cyclase-associated protein 1 (CAP1) regulates cofilin function, the actin cytoskeleton, and cell adhesion. J Biol Chem. 2013;288:20966-77.

84. Herscovics A. Structure and function of Class I alpha 1,2-mannosidases involved in glycoprotein synthesis and endoplasmic reticulum quality control. Biochimie. 2001;83:757-62.

85. Stegelmeier BL, James LF, Panter KE, Gardner DR, Pfister JA, Ralphs MH, Molyneux RJ. Dose response of sheep poisoned with locoweed (Oxytropis sericea). J Vet Diagn Invest. 1999;11:448-56.

86. Stegelmeier BL, James LF, Panter KE, Molyneux RJ. Tissue and serum swainsonine concentrations in sheep ingesting Astragalus lentiginosus (locoweed). Vet Hum Toxicol. 1995;37:336-9.

87. Yu PH, Davis BA, Boulton AA, Zuo DM. Deamination of aliphatic amines by type $B$ monoamine oxidase and semicarbazide-sensitive amine oxidase; pharmacological implications. J Neural Transm Suppl. 1994:41:397-406.

88. Sousse LE, Yamamoto Y, Enkhbaatar P, Rehberg SW, Wells SM, Leonard S, Traber MG, Yu YM, Cox RA, Hawkins HK, et al. Acute lung injury-induced collagen deposition is associated with elevated asymmetric dimethylarginine and arginase activity. Shock. 2011;35:282-8.

89. Sousse LE, Jonkam CC, Traber DL, Hawkins HK, Rehberg SW, Traber LD, Herndon DN, Enkhbaatar P. Pseudomonas aeruginosa is associated with increased lung cytokines and asymmetric dimethylarginine compared with methicillin-resistant Staphylococcus aureus. Shock. 2011;36:466-70.

90. Alemu P, Forsyth GW, Searcy GP. A comparison of parameters used to assess liver damage in sheep treated with carbon tetrachloride. Can J Comp Med. 1977:41:420-7.

91. Katsoulos PD, Christodoulopoulos G, Minas A, Karatzia MA, Pourliotis K, Kritas SK. The role of lactate dehydrogenase, alkaline phosphatase and aspartate aminotransferase in the diagnosis of subclinical intramammary infections in dairy sheep and goats. J Dairy Res. 2010;77:107-11.

92. Bodeker D, Oppelland G, Holler H. Involvement of carbonic anhydrase in ammonia flux across rumen mucosa in vitro. Exp Physiol. 1992;77:517-9.

93. Leonhard-Marek S, Gabel G, Martens H. Effects of short chain fatty acids and carbon dioxide on magnesium transport across sheep rumen epithelium. Exp Physiol. 1998;83:155-64.

94. Petrera A, Kern U, Linz D, Gomez-Auli A, Hohl M, Gassenhuber J, Sadowski T, Schilling O. Proteomic Profiling of Cardiomyocyte-Specific Cathepsin A Overexpression Links Cathepsin A to the Oxidative Stress Response. J Proteome Res. 2016:15:3188-95.

95. Kostadinov S, Shah BA, Alroy J, Phornphutkul C. A case of galactosialidosis with novel mutations of the protective protein/cathepsin a gene: diagnosis prompted by trophoblast vacuolization on placental examination. Pediatr Dev Pathol. 2014;17:474-7.

96. Hofmann F, Feil R, Kleppisch T, Schlossmann J. Function of cGMP-dependent protein kinases as revealed by gene deletion. Physiol Rev. 2006;86:1-23.

97. Bohr S, Patel SJ, Vasko R, Shen K, Golberg A, Berthiaume F, Yarmush ML. The Role of CHI3L1 (Chitinase-3-Like-1) in the Pathogenesis of Infections in Burns in a Mouse Model. PLoS One. 2015;10, e0140440.

98. Habib GM, Shi ZZ, Cuevas AA, Lieberman MW. Identification of two additional members of the membrane-bound dipeptidase family. FASEB J. 2003:17:1313-5.

99. Bebenek K, Kunkel TA. Functions of DNA polymerases. Adv Protein Chem. 2004:69:137-65.

100. Marcus F, Rittenhouse J, Gontero B, Harrsch PB. Function, structure and evolution of fructose-1,6-bisphosphatase. Arch Biol Med Exp (Santiago). 1987:20:371-8.

101. Visinoni S, Khalid NF, Joannides CN, Shulkes A, Yim M, Whitehead J, Tiganis T, Lamont BJ, Favaloro JM, Proietto J, et al. The role of liver fructose-1,6bisphosphatase in regulating appetite and adiposity. Diabetes. 2012;61:1122-32.

102. Woolliams JA, Wiener G, Anderson PH, McMurray CH. Variation in the activities of glutathione peroxidase and superoxide dismutase and in the concentration of copper in the blood in various breed crosses of sheep. Res Vet Sci. 1983;34:253-6. 
103. Carlile GW, Chalmers-Redman RME, Tatton NA, Pong A, Borden KLB, Tatton WG. Reduced Apoptosis after Nerve Growth Factor and Serum Withdrawal: Conversion of Tetrameric Glyceraldehyde-3-Phosphate Dehydrogenase to a Dimer. Mol Pharmacol. 2000;57:2-12.

104. Yugueros J, Temprano A, Berzal B, Sánchez M, Hernanz C, Luengo JM, Naharro G. Glyceraldehyde-3-Phosphate Dehydrogenase-Encoding Gene as a Useful Taxonomic Tool for Staphylococcusspp. J Clin Microbiol. 2000;38:4351-5.

105. Beavo JA. Cyclic nucleotide phosphodiesterases: functional implications of multiple isoforms. Physiol Rev. 1995;75:725-48.

106. Fritz TA, Hurley JH, Trinh LB, Shiloach J, Tabak LA. The beginnings of mucin biosynthesis: the crystal structure of UDP-GalNAc:polypeptide alpha-Nacetylgalactosaminyltransferase-T1. Proc Natl Acad Sci U S A. 2004;101:15307-12.

107. Tenno M, Kezdy FJ, Elhammer AP, Kurosaka A. Function of the lectin domain of polypeptide $\mathrm{N}$-acetylgalactosaminyltransferase 1. Biochem Biophys Res Commun. 2002;298:755-9.

108. Ramadoss J, Liao WX, Morschauser TJ, Lopez GE, Patankar MS, Chen DB, Magness RR. Endothelial caveolar hub regulation of adenosine triphosphateinduced endothelial nitric oxide synthase subcellular partitioning and domainspecific phosphorylation. Hypertension. 2012;59:1052-9.

109. Filali H, Martín-Burriel I, Harders F, Varona L, Hedman C, Mediano DR, Monzón M, Bossers A, Badiola JJ, Bolea R. Gene expression profiling of mesenteric lymph nodes from sheep with natural scrapie. BMC Genomics. 2014;15:1-17.

110. Yamashita H, Kotani T, Park JH, Murata Y, Okazawa H, Ohnishi H, Ku Y, Matozaki T. Role of the Protein Tyrosine Phosphatase Shp2 in Homeostasis of the Intestinal Epithelium. PLoS One. 2014;9, e92904.

111. Gurung RB, Begg DJ, Purdie AC, Bach H, Whittington RJ. Immunoreactivity of protein tyrosine phosphatase $A(\operatorname{PtpA})$ in sera from sheep infected with Mycobacterium avium subspecies paratuberculosis. Vet Immunol Immunopathol. 2014;160:129-32.

112. Steel EG, Witzel DA, Blanks A. Acquired coagulation factor $X$ activity deficiency connected with Hymenoxys odorata DC (Compositae), bitterweed poisoning in sheep. Am J Vet Res. 1976;37:1383-6.

113. Tillman P, Carson SN, Talken L. Platelet function and coagulation parameters in sheep during experimental vascular surgery. Lab Anim Sci. 1981;31:263-7.

114. Filippovich I, Sorokina N, St Pierre L, Flight S, de Jersey J, Perry N, Masci PP, Lavin MF. Cloning and functional expression of venom prothrombin activator protease from Pseudonaja textilis with whole blood procoagulant activity. Br J Haematol. 2005;131:237-46.

115. Klee L, Zand R. Probable epitopes: Relationships between myelin basic protein antigenic determinants and viral and bacterial proteins. Neuroinformatics. 2004;2:59-70.

116. Bongaerts GP, Vogels GD. Mechanism of uricase action. Biochim Biophys Acta. 1979:567:295-308.

117. Rietema SE, Blackberry MA, Maloney SK, Martin GB, Hawken PA, Blache D. Twenty-four-hour profiles of metabolic and stress hormones in sheep selected for a calm or nervous temperament. Domest Anim Endocrinol. 2015:53:78-87.

118. Chemonges $\mathrm{S}$. Suspected selective susceptibility to endotoxin in an ovine model. Online J Vet Res. 2014:18:941-63.

119. Almeida AM, Palhinhas RG, Kilminster T, Scanlon T, van Harten S, Milton J, Blache D, Greeff J, Oldham C, Coelho AV, Cardoso LA. The Effect of Weight Loss on the Muscle Proteome in the Damara, Dorper and Australian Merino Ovine Breeds. PLoS One. 2016;11, e0146367.

120. Knight TW, Lindsay DR, Oldham CM. Proceedings: the influence of rams on the fertility of the ewe. J Reprod Fertil. 1975;43:377-8.

121. Brown HM, Fabre Nys C, Cognie J, Scaramuzzi RJ. Short oestrous cycles in sheep during anoestrus involve defects in progesterone biosynthesis and luteal neovascularisation. Reproduction. 2014;147:357-67.

122. Mitchell LM, King ME, Aitken RP, Gebbie FE, Wallace JM. Ovulation, fertilization and lambing rates, and peripheral progesterone concentrations, in ewes inseminated at a natural oestrus during November or February. J Reprod Fertil. 1999;115:133-40.

123. Tung JP, Fung YL, Nataatmadja M, Colebourne Kl, Esmaeel HM, Wilson K, Barnett AG, Wood P, Silliman CC, Fraser JF. A novel in vivo ovine model of transfusion-related acute lung injury (TRALI). Vox Sang. 2011;100:219-30.

124. Australian code of practice for the care and use of animals for scientific purposes [https://www.nhmrc.gov.au/guidelines-publications/ea28]. Accessed 4 Aug 2016.

\section{Submit your next manuscript to BioMed Central and we will help you at every step:}

- We accept pre-submission inquiries

- Our selector tool helps you to find the most relevant journal

- We provide round the clock customer support

- Convenient online submission

- Thorough peer review

- Inclusion in PubMed and all major indexing services

- Maximum visibility for your research

Submit your manuscript at www.biomedcentral.com/submit 